\title{
LEVEL II SCOUR ANALYSIS FOR BRIDGE 16 (STRATH00180016) on TOWN HIGHWAY 18, crossing the WEST BRANCH OMPOMPANOOSUC RIVER, STRAFFORD, VERMONT
}

U.S. Geological Survey

Open-File Report 98-024

Prepared in cooperation with

VERMONT AGENCY OF TRANSPORTATION

and

FEDERAL HIGHWAY ADMINISTRATION

U.S. Department of the Interior

U.S. Geological Survey

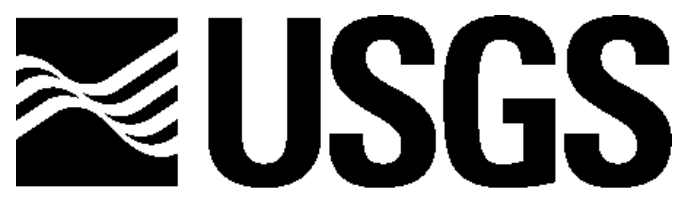

science for a changing world 


\section{LEVEL II SCOUR ANALYSIS FOR BRIDGE 16 (STRATH00180016) on TOWN HIGHWAY 18, crossing the WEST BRANCH OMPOMPANOOSUC RIVER, STRAFFORD, VERMONT \\ By LORA K. STRIKER AND MICHAEL A. IVANOFF \\ U.S. Geological Survey \\ Open-File Report 98-024}

Prepared in cooperation with

VERMONT AGENCY OF TRANSPORTATION and

FEDERAL HIGHWAY ADMINISTRATION 


\title{
U.S. DEPARTMENT OF THE INTERIOR BRUCE BABBITT, Secretary
}

\author{
U.S. GEOLOGICAL SURVEY
}

Thomas J. Casadevall, Acting Director

For additional information write to:

District Chief

U.S. Geological Survey 361 Commerce Way

Pembroke, NH 03275-3718
Copies of this report may be purchased from:

U.S. Geological Survey

Branch of Information Services

Open-File Reports Unit

Box 25286

Denver, CO 80225-0286 


\section{CONTENTS}

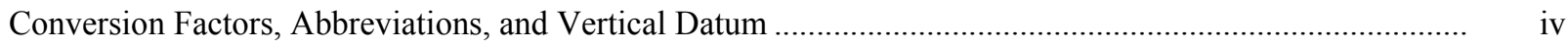

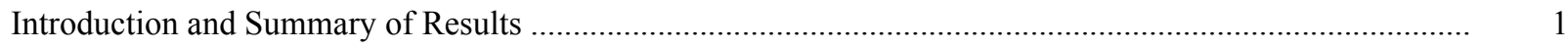

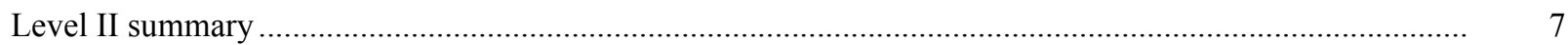

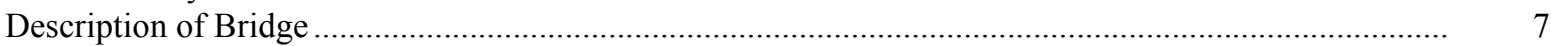

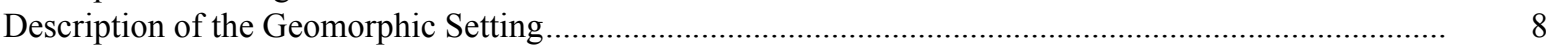

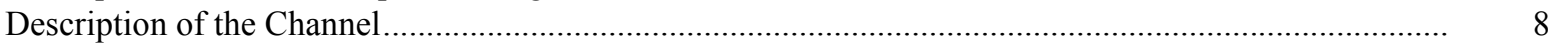

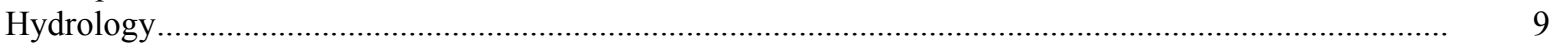

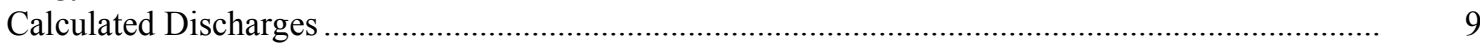

Description of the Water-Surface Profile Model (WSPRO) Analysis .................................................... 10

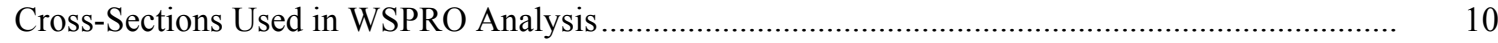

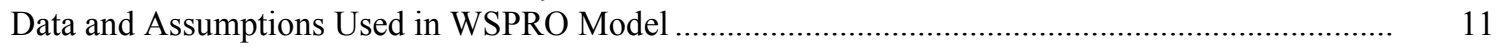

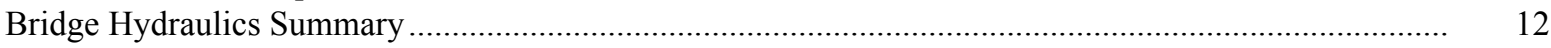

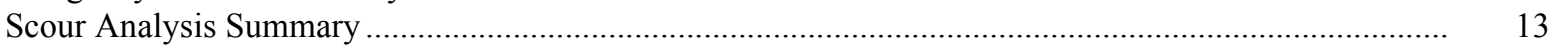

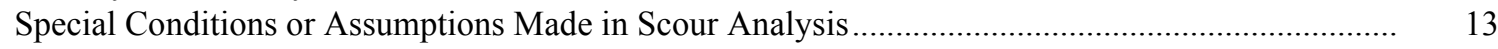

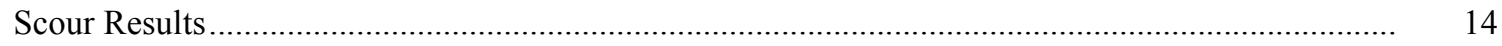

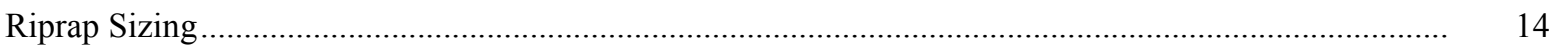

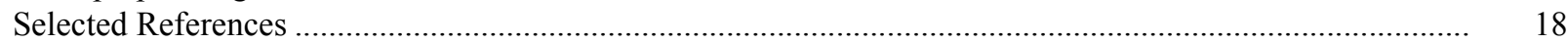

Appendices:

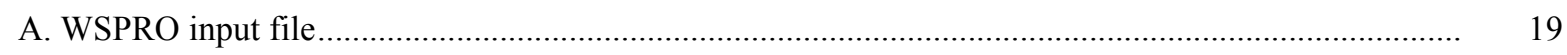

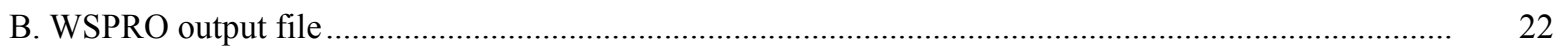

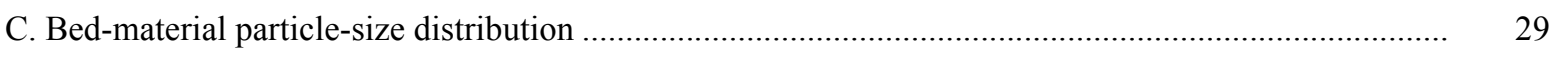

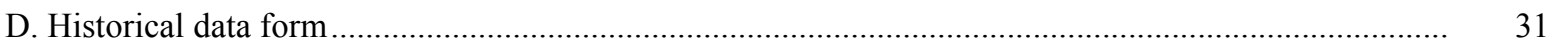

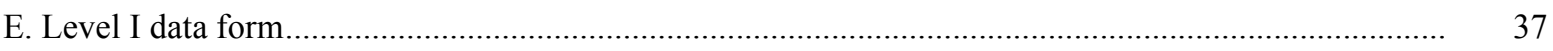

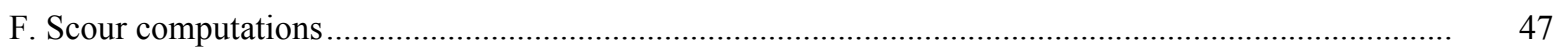

\section{FIGURES}

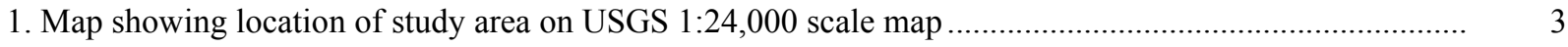

2. Map showing location of study area on Vermont Agency of Transportation town

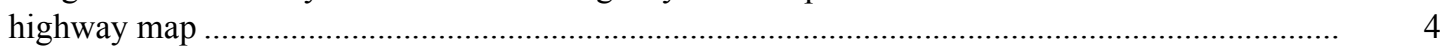

3. Structure STRATH00180016 viewed from upstream (October 19, 1995) ….......................................... 5

4. Downstream channel viewed from structure STRATH00180016 (October 19, 1995). ............................ 5

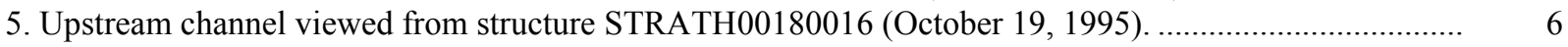

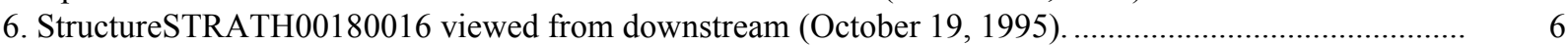

7. Water-surface profiles for the 100- and 500-year discharges at structure

STRATH00180016 on Town Highway 18, crossing the West Branch Ompompanoosuc River Strafford, Vermont.

8. Scour elevations for the 100- and 500-year discharges at structure

STRATH00180016 on Town Highway 18, crossing the West Branch Ompompanoosuc River

Strafford, Vermont.

\section{TABLES}

1. Remaining footing/pile depth at abutments for the 100-year discharge at structure STRATH00180016 on Town Highway 18, crossing the West Branch Ompompanoosuc River Strafford, Vermont

2. Remaining footing/pile depth at abutments for the 500-year discharge at structure

STRATH00180016 on Town Highway 18, crossing the West Branch Ompompanoosuc River Strafford, Vermont 


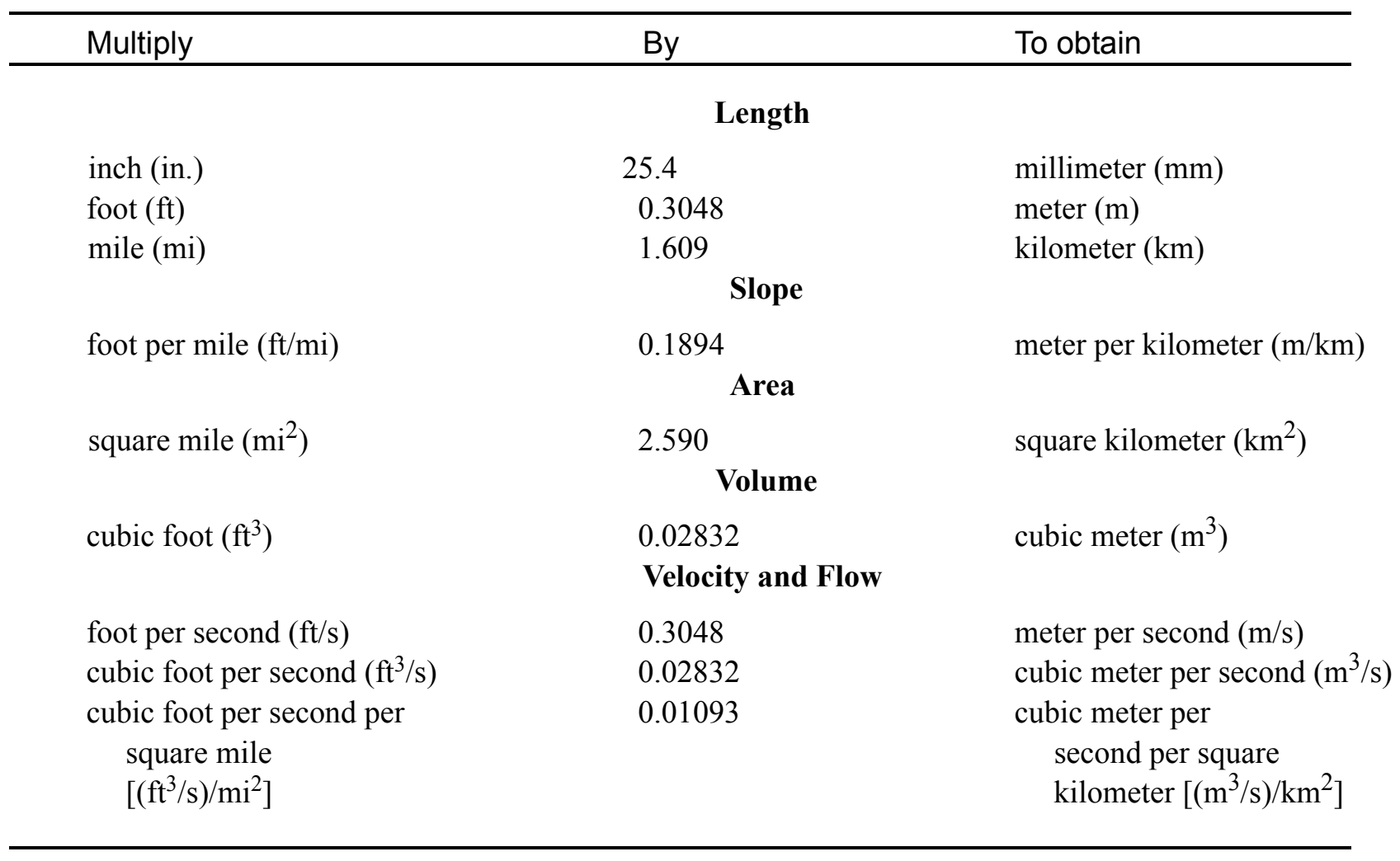

\section{OTHER ABBREVIATIONS}

$\begin{array}{lrlr}\mathrm{BF} & \text { bank full } & \text { LWW } & \text { left wingwall } \\ \mathrm{cfs} & \text { cubic feet per second } & \text { MC } & \text { main channel } \\ \mathrm{D}_{50} & \text { median diameter of bed material } & \text { RAB } & \text { right abutment } \\ \mathrm{DS} & \text { downstream } & \text { RABUT } & \text { face of right abutment } \\ \mathrm{elev} & \text { elevation } & \text { RB } & \text { right bank } \\ \mathrm{f} / \mathrm{p} & \text { flood plain } & \text { ROB } & \text { right overbank } \\ \mathrm{ft}^{2} & \text { square feet } & \text { RWW } & \text { right wingwall } \\ \mathrm{ft} / \mathrm{ft} & \text { feet per foot } & \text { TH } & \text { town highway } \\ \mathrm{JCT} & \text { junction } & \text { UB } & \text { under bridge } \\ \mathrm{LAB} & \text { left abutment } & \text { US } & \text { upstream } \\ \mathrm{LABUT} & \text { face of left abutment } & \text { USGS } & \text { United States Geological Survey } \\ \mathrm{LB} & \text { left bank } & \text { VTAOT Vermont Agency of Transportation } \\ \mathrm{LOB} & \text { left overbank } & \text { WSPRO } & \text { water-surface profile model }\end{array}$

In this report, the words "right" and "left" refer to directions that would be reported by an observer facing downstream. Sea level: In this report, "sea level" refers to the National Geodetic Vertical Datum of 1929-- a geodetic datum derived from a general adjustment of the first-order level nets of the United States and Canada, formerly called Sea Level Datum of 1929.

In the appendices, the above abbreviations may be combined. For example, USLB would represent upstream left bank. 


\title{
LEVEL II SCOUR ANALYSIS FOR BRIDGE 16 (STRATH00180016) ON TOWN HIGHWAY 18, CROSSING THE WEST BRANCH OMPOMPANOOSUC RIVER, STRAFFORD, VERMONT
}

\author{
By Lora K. Striker and Michael A. Ivanoff
}

\section{INTRODUCTION AND SUMMARY OF RESULTS}

This report provides the results of a detailed Level II analysis of scour potential at structure STRATH00180016 on Town Highway 18 crossing the West Branch Ompompanoosuc River, Strafford, Vermont (figures 1-8). A Level II study is a basic engineering analysis of the site, including a quantitative analysis of stream stability and scour (Federal Highway Administration, 1993). Results of a Level I scour investigation also are included in appendix $\mathrm{E}$ of this report. A Level I investigation provides a qualitative geomorphic characterization of the study site. Information on the bridge, gleaned from Vermont Agency of Transportation (VTAOT) files, was compiled prior to conducting Level I and Level II analyses and is found in appendix D.

The site is in the New England Upland section of the New England physiographic province in east-central Vermont. The $6.28-\mathrm{mi}^{2}$ drainage area is in a predominantly rural and forested basin. In the vicinity of the study site, the surface cover is predominantly forest. Surface cover on the upstream right bank is shrub and brushland.

In the study area, the West Branch Ompompanoosuc River has an incised, sinuous channel with a slope of approximately $0.03 \mathrm{ft} / \mathrm{ft}$, an average channel top width of $32 \mathrm{ft}$ and an average bank height of $3 \mathrm{ft}$. The channel bed material ranges from gravel to boulder with a median grain size $\left(\mathrm{D}_{50}\right)$ of $64.5 \mathrm{~mm}(0.212 \mathrm{ft})$. The geomorphic assessment at the time of the Level I and Level II site visit on October 19, 1995, indicated that the reach was stable.

The Town Highway 18 crossing of the West Branch Ompompanoosuc River is a 35-ft-long, one-lane bridge consisting of two 11-foot rail-road stringer spans with a timber deck (Vermont Agency of Transportation, written communication, March 23, 1995). The opening length of the structure parallel to the bridge face is $21.6 \mathrm{ft}$. The bridge is supported by vertical, concrete abutments with wingwalls. The channel is skewed approximately 0 degrees to the opening while the computed opening-skew-to-roadway is 5 degrees. 
Although there was no channel scour observed during the Level I assessment, the left abutment footing was exposed $1.0 \mathrm{ft}$ and the right abutment footing was exposed $0.5 \mathrm{ft}$. Scour protection measures at the site include: type- 2 stone fill (less than 36 inches diameter) along the upstream left and right banks, along the entire base length of the upstream left and right wingwalls, left and right abutments, downstream left and right wingwalls, and downstream left and right banks. Additional details describing conditions at the site are included in the Level II Summary and appendices D and E.

Scour depths and recommended rock rip-rap sizes were computed using the general guidelines described in Hydraulic Engineering Circular 18 (Richardson and Davis, 1995). Total scour at a highway crossing is comprised of three components: 1) long-term streambed degradation; 2) contraction scour (due to accelerated flow caused by a reduction in flow area at a bridge) and; 3 ) local scour (caused by accelerated flow around piers and abutments). Total scour is the sum of the three components. Equations are available to compute depths for contraction and local scour and a summary of the results of these computations follows.

Contraction scour for all modelled flows was $0.0 \mathrm{ft}$. Abutment scour ranged from 3.4 to 7.5 $\mathrm{ft}$. The worst-case abutment scour occurred at the 500-year discharge. Pier scour ranged from 2.1 to $2.2 \mathrm{ft}$. The worst case pier scour occurred at the incipient-overtopping discharge. Additional information on scour depths and depths to armoring are included in the section titled "Scour Results". Scoured-streambed elevations, based on the calculated scour depths, are presented in tables 1 and 2. A cross-section of the scour computed at the bridge is presented in figure 8. Scour depths were calculated assuming an infinite depth of erosive material and a homogeneous particle-size distribution.

It is generally accepted that the Froehlich equation (abutment scour) gives "excessively conservative estimates of scour depths" (Richardson and Davis, 1995, p. 47). Usually, computed scour depths are evaluated in combination with other information including (but not limited to) historical performance during flood events, the geomorphic stability assessment, existing scour protection measures, and the results of the hydraulic analyses. Therefore, scour depths adopted by VTAOT may differ from the computed values documented herein. 


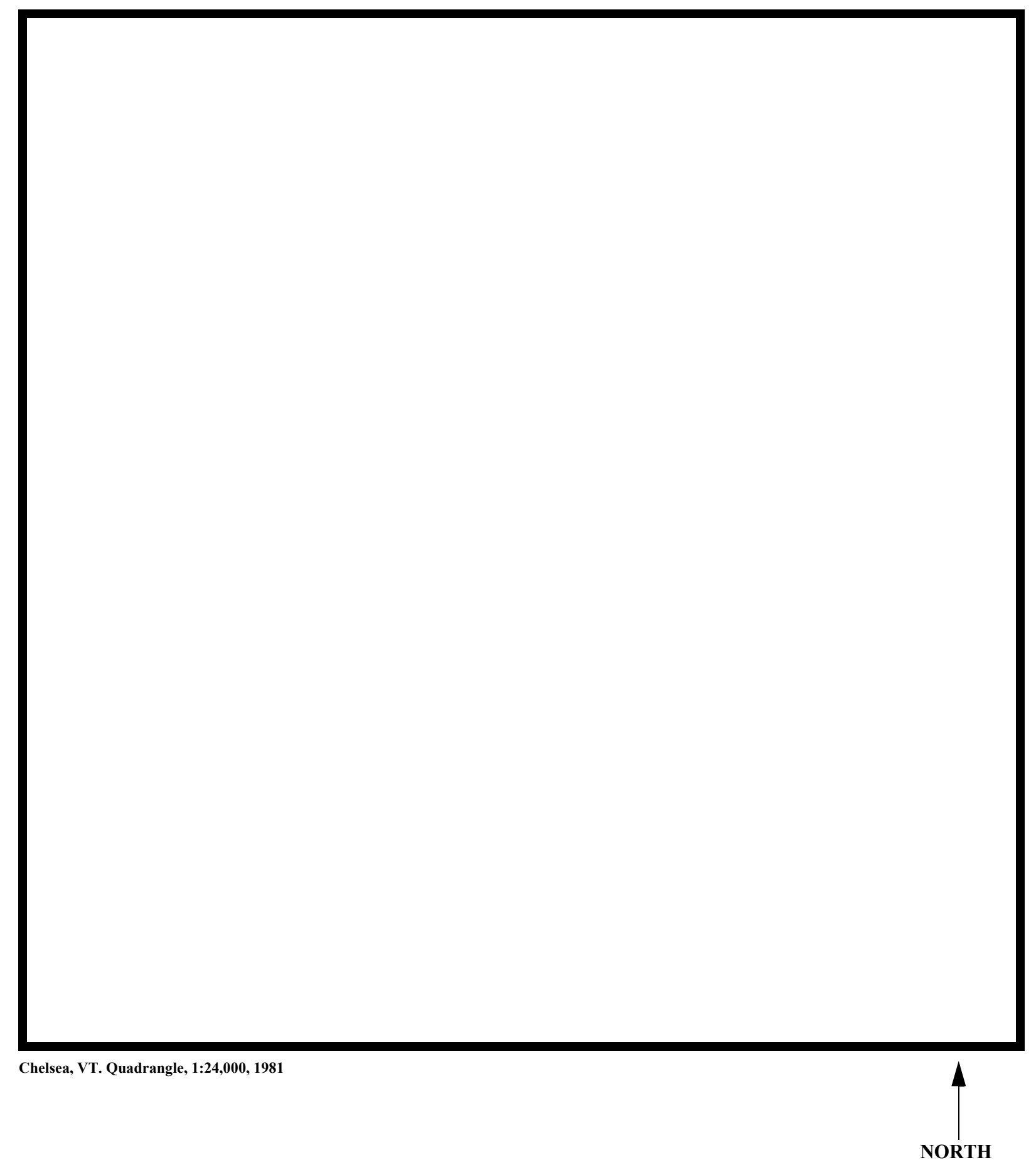

Figure 1. Location of study area on USGS 1:24,000 scale map. 
Figure 2. Location of study area on Vermont Agency of Transportation town highway map. 

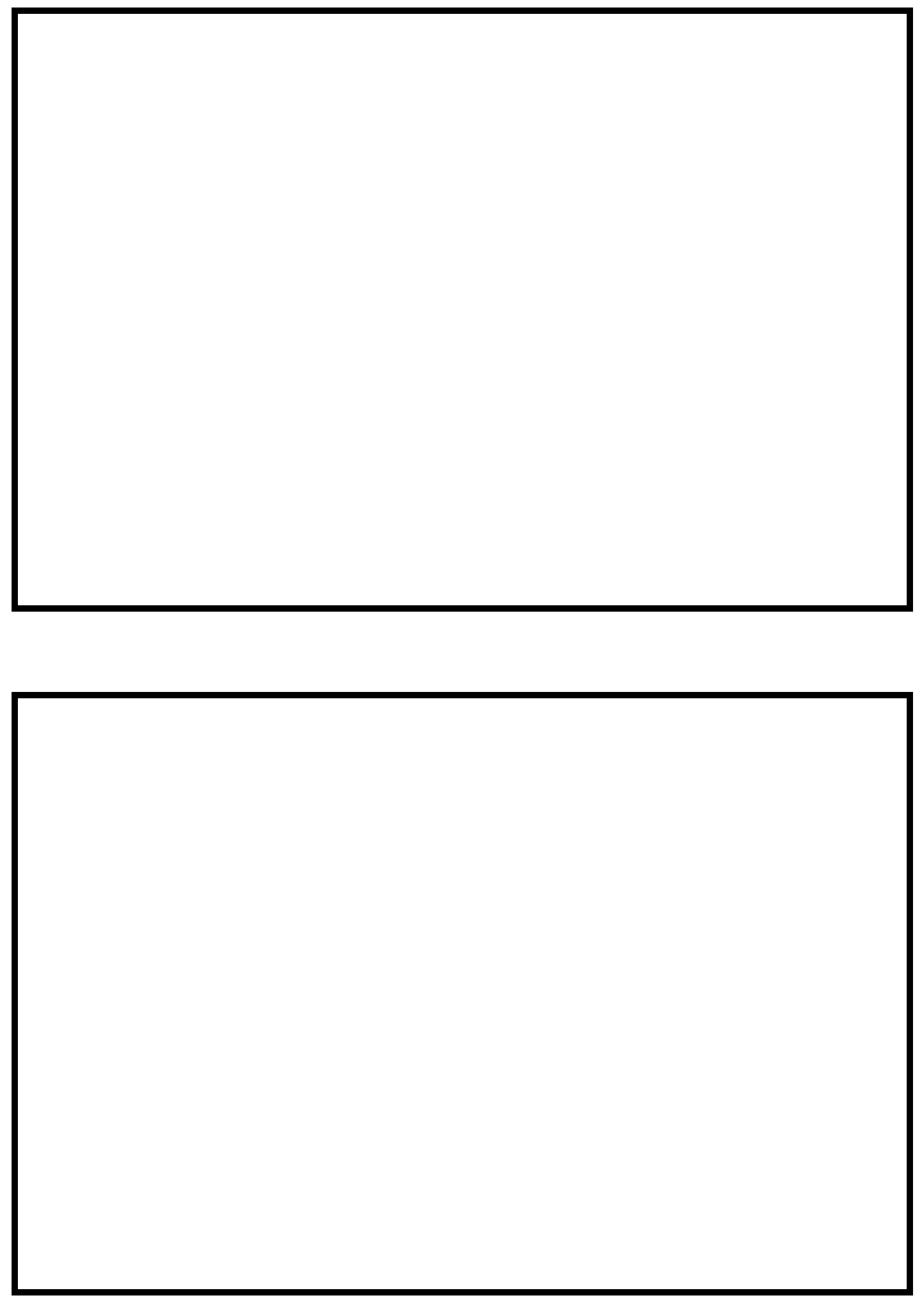

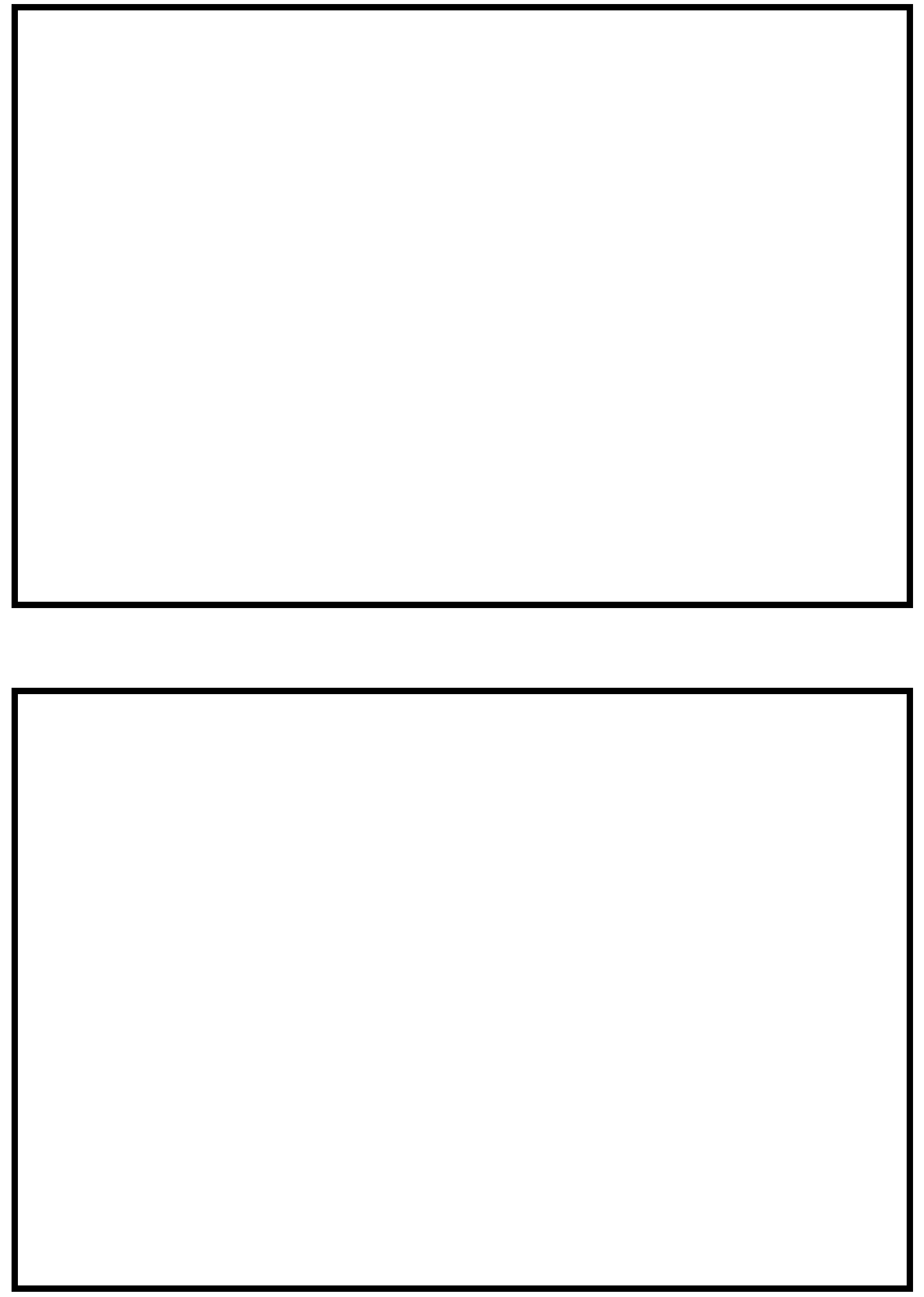


\section{LEVEL II SUMMARY}

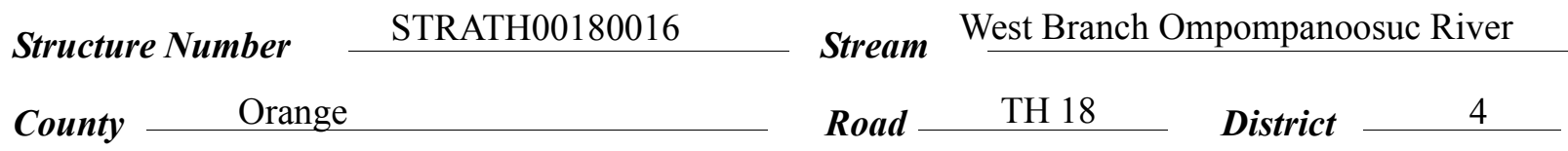

\section{Description of Bridge}

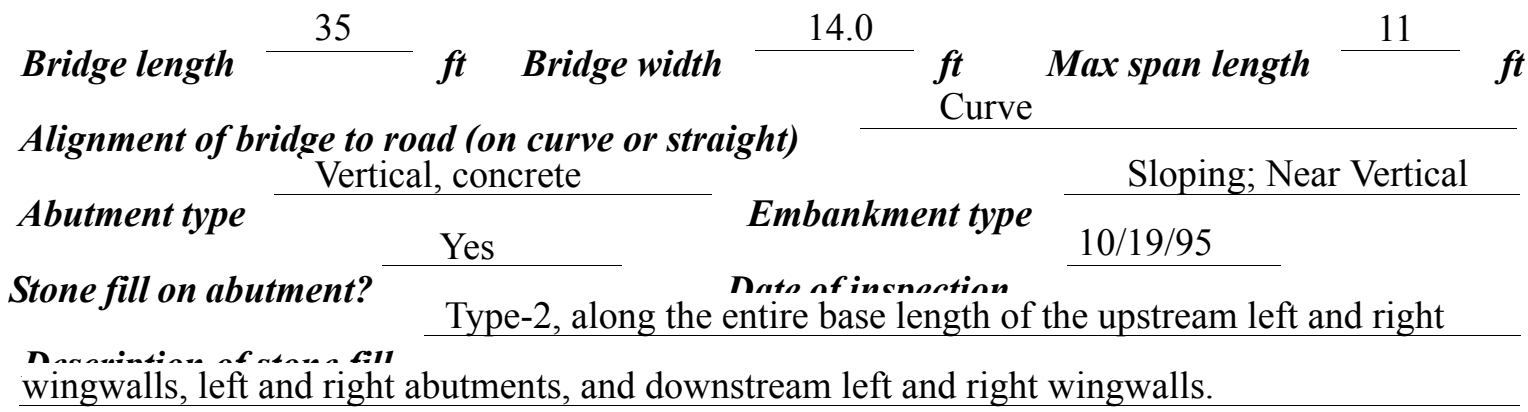

Abutments and wingwalls are concrete. The pier has

square wooden piles with a concrete footing.

Is bridge skewed to flood flow according to $\mathrm{No}^{\mathrm{N}}$ survey?

Debris accumulation on bridge at time of Level I or Level II site visit:

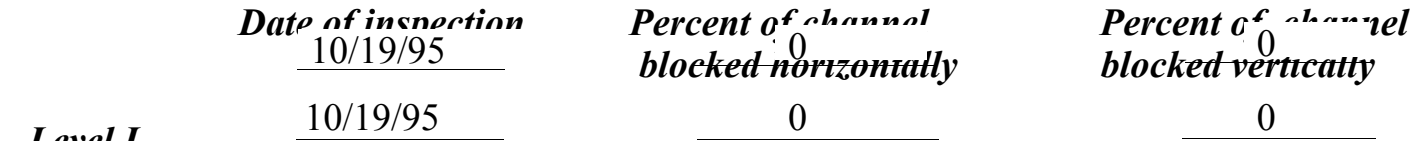

Level II $\quad$ Moderate. Although the natural bank material protects trees from falling into the channel, the debris potential is moderate due to the timber pier.

Potential for debris

None as of 10/19/95.

Doscriho any, foaturos noar ar at tho hridoo that mav, affort flou, (includo ahsorvation dato) 


\section{Description of the Geomorphic Setting}

General topography The channel is located within a moderate relief valley with a narrow flood plain and steep valley walls on both sides.

Geomorphic conditions at bridge site: downstream (DS), upstream (US)

Date of inspection $\quad 10 / 19 / 95$

DS left: $\quad$ Steep channel bank to irregular overbank and steep valley wall

DS right: $\quad$ Steep channel bank to narrow flood plain and steep valley wall

US left: $\quad$ Steep channel bank to irregular overbank and steep valley wall

US right: $\quad$ Steep channel bank to narrow flood plain and steep valley wall

\section{Description of the Channel}

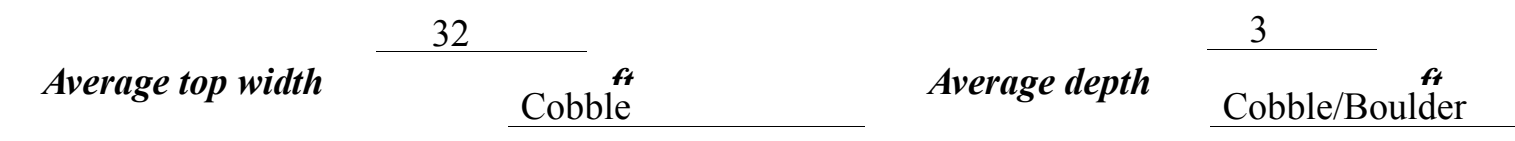

Predominant bed material Bank material Perennial, sinuous,

incised, and stable channel with non-alluvial channel boundarië.

$10 / 19 / 95$

Vegetative co 1 Small trees and short grass

DS left: $\quad$ Small trees and short grass

DS right: $\quad$ Small trees and short grass

US left: $\quad$ Small trees and short grass

US right: $\quad$ Yes

Do banks appear stable? -

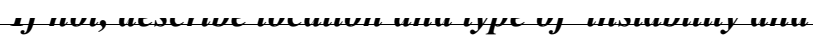

date of observatton.

None as of 10/19/95.

Describe any obstructions in channel and date of observation. 


\title{
Hydrology
}

Drainage area $\quad 6.3 \quad \boldsymbol{m i}^{2}$

Percentage of drainage area in physiographic provinces: (approximate)

Physiographic province/section New England/New England Upland
Percent of drainage area 100

\begin{abstract}
Is drainage area considered rural or urban? $\quad$ Rural Describe any significant urbanization:
\end{abstract}

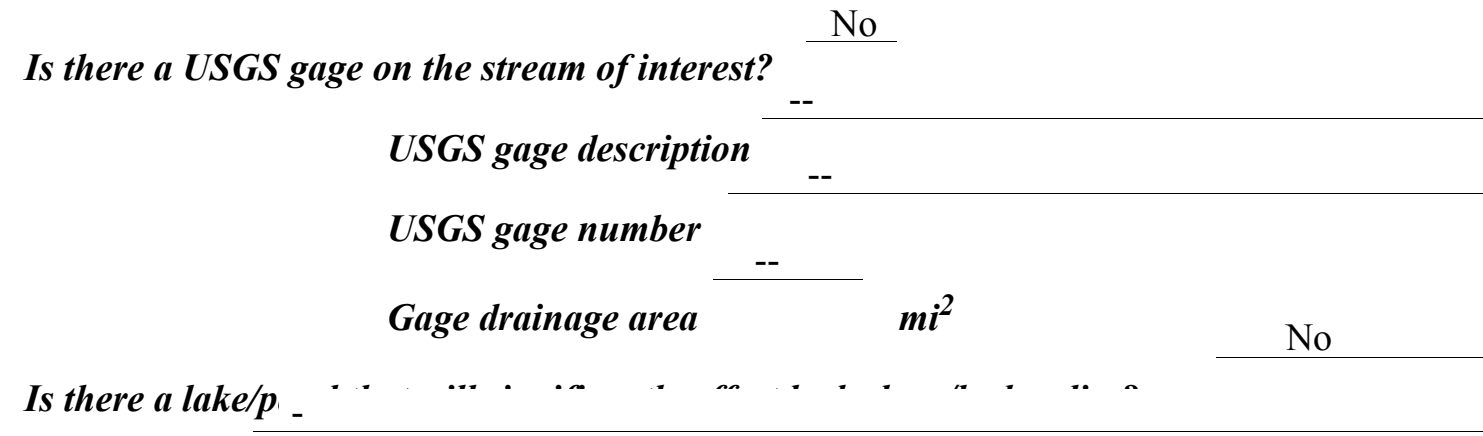

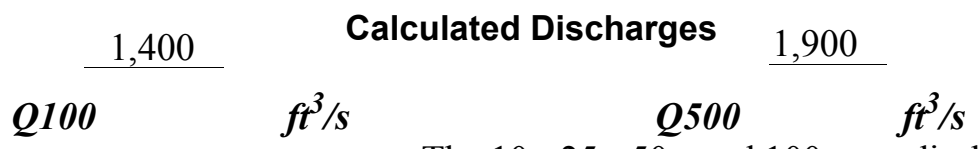

The 10-, 25-, 50-, and 100-year discharges were

taken from the VTAOT database (Vermont Agency of Transportation, written communication, May 1995) and extrapolated to the 500-year event. The VTAOT discharges fall within a range defined by several empirical methods (Benson, 1962; Johnson and Tasker, 1974; FHWA, 1983;

Potter, 1957a\&b; Talbot, 1887). 


\section{Description of the Water-Surface Profile Model (WSPRO) Analysis}

Datum for WSPRO analysis (USGS survey, sea level, VTAOT plans)

USGS survey

Datum tie between USGS survey and VTAOT plans

None

Description of reference marks used to determine USGS datum. $\quad$ RM1 is a chiseled X at

the US end of the left abutment (elev. $498.76 \mathrm{ft}$, arbitrary survey datum). RM2 is a chiseled X at

the DS end of the right abutment (elev. $499.65 \mathrm{ft}$, arbitrary survey datum). RM3 is a nail $6.5 \mathrm{ft}$

from the ground in telephone pole \#2311804/12, $95 \mathrm{ft}$ upstream and $30 \mathrm{ft}$ left from the center of

the left abutment (elev. 507.29, arbitrary survey datum).

\section{Cross-Sections Used in WSPRO Analysis}

\begin{tabular}{|c|c|c|c|}
\hline${ }^{1}$ Cross-section & $\begin{array}{c}\text { Section } \\
\text { Reference } \\
\text { Distance } \\
\text { (SRD) in feet }\end{array}$ & $\begin{array}{l}{ }^{2} \text { Cross-section } \\
\text { development }\end{array}$ & Comments \\
\hline EXIT1 & -144 & 3 & $\begin{array}{l}\text { Exit section (overbanks } \\
\text { modified from EXIT2) }\end{array}$ \\
\hline EXIT2 & -23 & 1 & Exit section \\
\hline FULLV & 0 & 2 & $\begin{array}{l}\text { Downstream Full-valley } \\
\text { section (Templated from } \\
\text { EXIT2) }\end{array}$ \\
\hline BRIDG & 0 & 1 & Bridge section \\
\hline RDWAY & 7 & 1 & Road Grade section \\
\hline APPRO & 34 & 2 & $\begin{array}{l}\text { Approach section as sur- } \\
\text { veyed (Used as a tem- } \\
\text { plate) }\end{array}$ \\
\hline
\end{tabular}

${ }^{1}$ For location of cross-sections see plan-view sketch included with Level I field form, Appendix E. For more detail on how cross-sections were developed see WSPRO input file. 


\section{Data and Assumptions Used in WSPRO Model}

Hydraulic analyses of the reach were done by use of the Federal Highway Administration's WSPRO step-backwater computer program (Shearman and others, 1986, and Shearman, 1990). The analyses reported herein reflect conditions existing at the site at the time of the study. Furthermore, in the development of the model it was necessary to assume no accumulation of debris or ice at the site. Results of the hydraulic model are presented in the Bridge Hydraulic Summary, appendix B, and figure 7.

Channel roughness factors (Manning's " $n$ ") used in the hydraulic model were estimated using field inspections at each cross section following the general guidelines described by Arcement and Schneider (1989). Final adjustments to the values were made during the modelling of the reach. Channel " $\mathrm{n}$ " values for the reach ranged from 0.050 to 0.060 , and overbank " $n$ " values ranged from 0.041 to 0.065 .

Normal depth at the exit section (EXIT1) was assumed as the starting water surface for the incipient-overtopping discharge model. This depth was computed by use of the slopeconveyance method outlined in the user's manual for WSPRO (Shearman, 1990). The slope used was $0.0290 \mathrm{ft} / \mathrm{ft}$, which was estimated from the topographic map (U.S. Geological Survey, 1981). Critical depth at the exit section (EXIT1) was assumed as the starting water surface elevation for the 100- and 500-year discharge. The computed normal depths were within $0.3 \mathrm{ft}$ of critical depth by use of the slope-conveyance method. Therefore, the critical water surface was assumed to be a satisfactory starting water surface for the 100- and 500-year discharge models.

The approach section (APPRO) was surveyed one bridge length upstream of the upstream face as recommended by Shearman and others (1986). This location provides a consistent method for determining scour variables. 


\section{Bridge Hydraulics Summary}

$\begin{array}{llll}\text { Average bridge embankment elevation } & 500.0 & f t \\ \text { Average low steel elevation } & 499.0 & \boldsymbol{f t}\end{array}$

100-year discharge $\quad 1,400 \quad \mathrm{ft}^{3} / \mathrm{s}$

Water-surface elevation in bridge opening $499.1 \quad f t$

Road overtopping? ___ Yes Discharge over road _ $649 \quad \mathrm{ft}^{3} / \mathrm{s}$

\begin{tabular}{llll} 
Area of flow in bridge opening & \multicolumn{1}{c}{\begin{tabular}{c}
101 \\
\cline { 2 - 3 }
\end{tabular} Average velocity in bridge opening } & 7.1 & $\mathrm{ft} / \mathrm{s}$
\end{tabular}

Maximum WSPRO tube velocity at bridge $\quad 8.3 \mathrm{ft} / \mathrm{s}$

Water-surface elevation at Approach section with bridge $\quad 500.1$

Water-surface elevation at Approach section without bridge $\quad \overline{499.6}$

Amount of backwater caused by bridge

0.5 it

500-year discharge $\quad 1,900 \quad \mathrm{ft}^{3} / \mathrm{s}$

Water-surface elevation in bridge opening

$499.1 \mathrm{ft}$

Road overtopping? ___ Yes Discharge over road __ $1,150, \mathrm{H}^{3} / \mathrm{s}$

Area of flow in bridge opening

Average velocity in bridge opening

\begin{tabular}{rrr}
101 & $\boldsymbol{f t}^{2}$ & \\
& & \\
& 7.2 & $\boldsymbol{f t} / \mathbf{s}$ \\
\cline { 2 - 3 } & & $8.4 \quad \mathrm{~s}$
\end{tabular}

Maximum WSPRO tube velocity at bridge

(1)

500.6

Water-surface elevation at Approach section with bridge

Water-surface elevation at Approach section without bridge

Amount of backwater caused by bridge

0.4 it

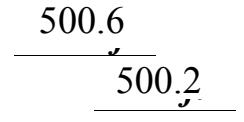

Incipient overtopping discharge $\quad 520 \quad \mathrm{ft}^{3} / \mathrm{s}$

Water-surface elevation in bridge opening $497.4 \quad$ t

Area of flow in bridge opening

$71 \quad \boldsymbol{f t}^{2}$

Average velocity in bridge opening

Maximum WSPRO tube velocity at bridge

Water-surface elevation at Approach section with bridge

Water-surface elevation at Approach section without bridge

498.3

Amount of backwater caused by bridge

0.3 , $t$

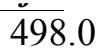




\section{Scour Analysis Summary}

\section{Special Conditions or Assumptions Made in Scour Analysis}

Scour depths were computed using the general guidelines described in Hydraulic Engineering Circular 18 (Richardson and Davis, 1995). Scour depths were calculated assuming an infinite depth of erosive material and a homogeneous particle-size distribution. The results of the scour analysis for the 100- and 500-year discharges are presented in tables 1 and 2 and figure 8.

Contraction scour for the 100-year, 500-year, and incipient roadway-overtopping discharges was computed by use of the Laursen clear-water contraction scour equation (Richardson and Davis, 1995, p. 32, equation 20). At this site, the 100- and 500-year discharges resulted in submerged orifice flow. Contraction scour at bridges with orifice flow is best estimated by use of the Chang pressure-flow scour equation (oral communication, J. Sterling Jones, October 4, 1996). Thus, contraction scour for these discharges was computed by use of the Chang equation (Richardson and Davis, 1995, p. 145-146). The streambed armoring depths computed suggest that armoring will not limit the depth of contraction scour.

For comparison, estimates of contraction scour for the discharges resulting in orifice flow were also computed by use of the Laursen clear-water contraction scour equation and the Umbrell pressure-flow equation (Richardson and Davis, 1995, p. 144) and presented in appendix F.

Abutment scour was computed by use of the Froehlich equation (Richardson and Davis, 1995, p. 48, equation 28). Variables for the Froehlich equation include the Froude number of the flow approaching the embankments, the length of the embankment blocking flow, and the depth of flow approaching the embankment less any roadway overtopping.

Pier scour was computed by use of an equation based on the Colorado State University equation (Richardson and Davis, 1995, p. 36, eq. 21). Variables for the equation include: pier length, pier width, approach velocity and correction factors for pier shape, flow attack angle, streambed condition, streambed armoring, and average depth and maximum velocity (for the froude number) immediately upstream of the bridge. 


\section{Scour Results}

\section{0-yr discharge 500-yr discharge}

Contraction scour:

(Scour depths in feet)

Main channel

Live-bed scour

Clear-water scour

Depth to armoring

Left overbank

Right overbank

Local scour:

Abutment scour

Left abutment

Right abutment

Pier scour
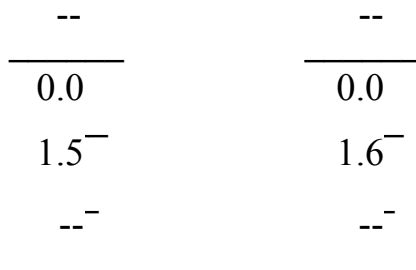

$--$

overtopping discharge

Incipient

Left abutment
Right abutment

Pier 1

6.2

5.7

3.4

7.2

$7.5-$

4.9-

Pier 2

Pier 3
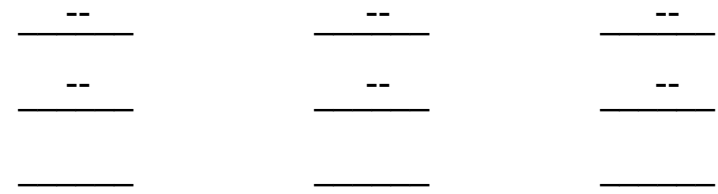

\section{Riprap Sizing}

Abutments:

Left abutment

Right abutment

Piers:

Pier 1

Pier 2

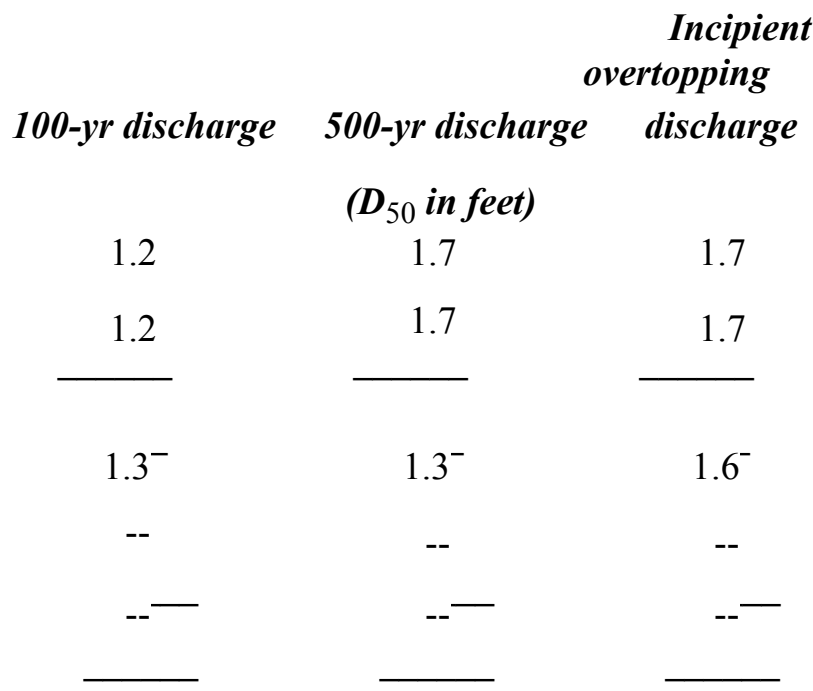




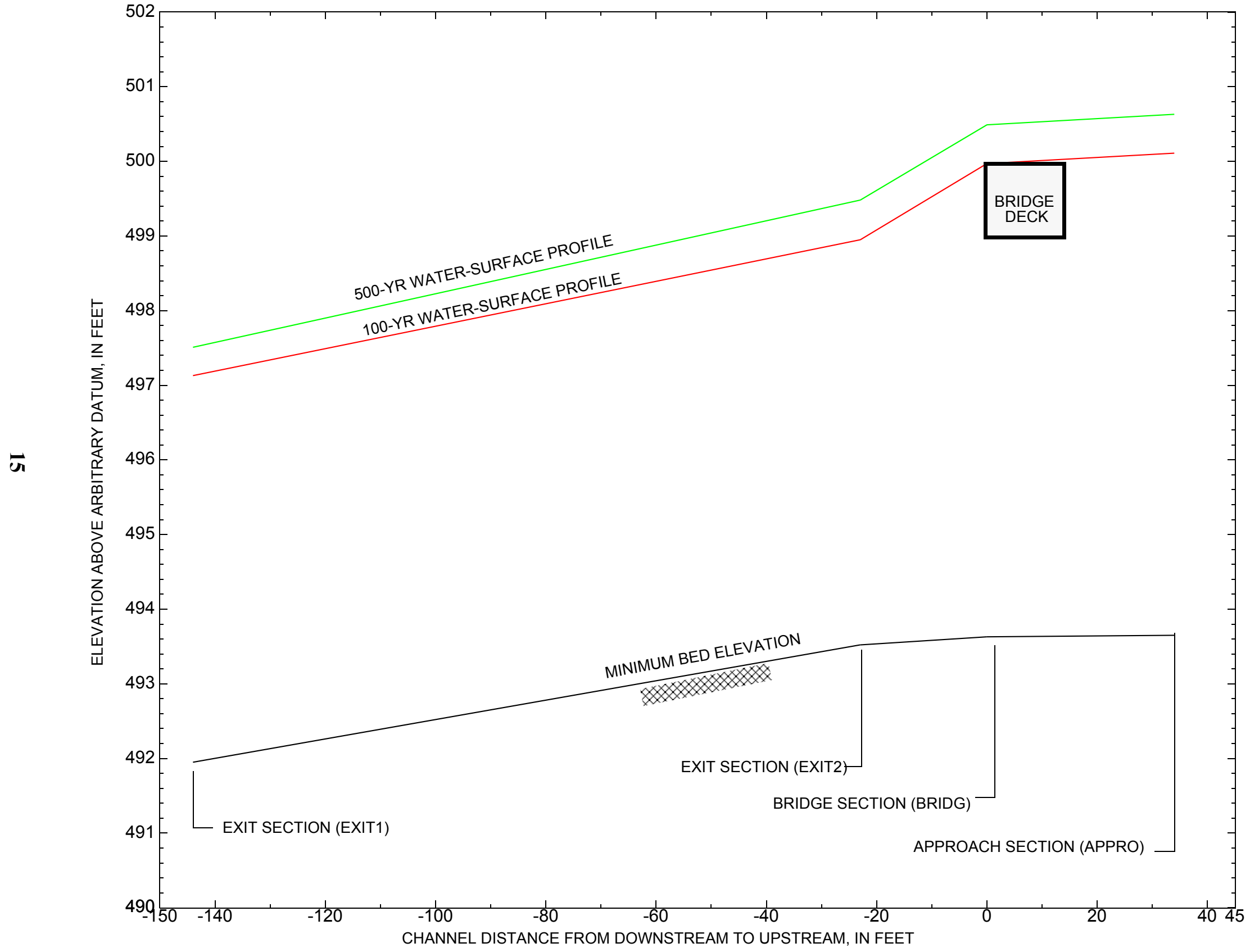

Figure 7. Water-surface profiles for the 100- and 500-year discharges at structure STRATH00180016 on Town Highway 18, crossing the West Branch Ompompanoosuc River, Strafford, Vermont. 


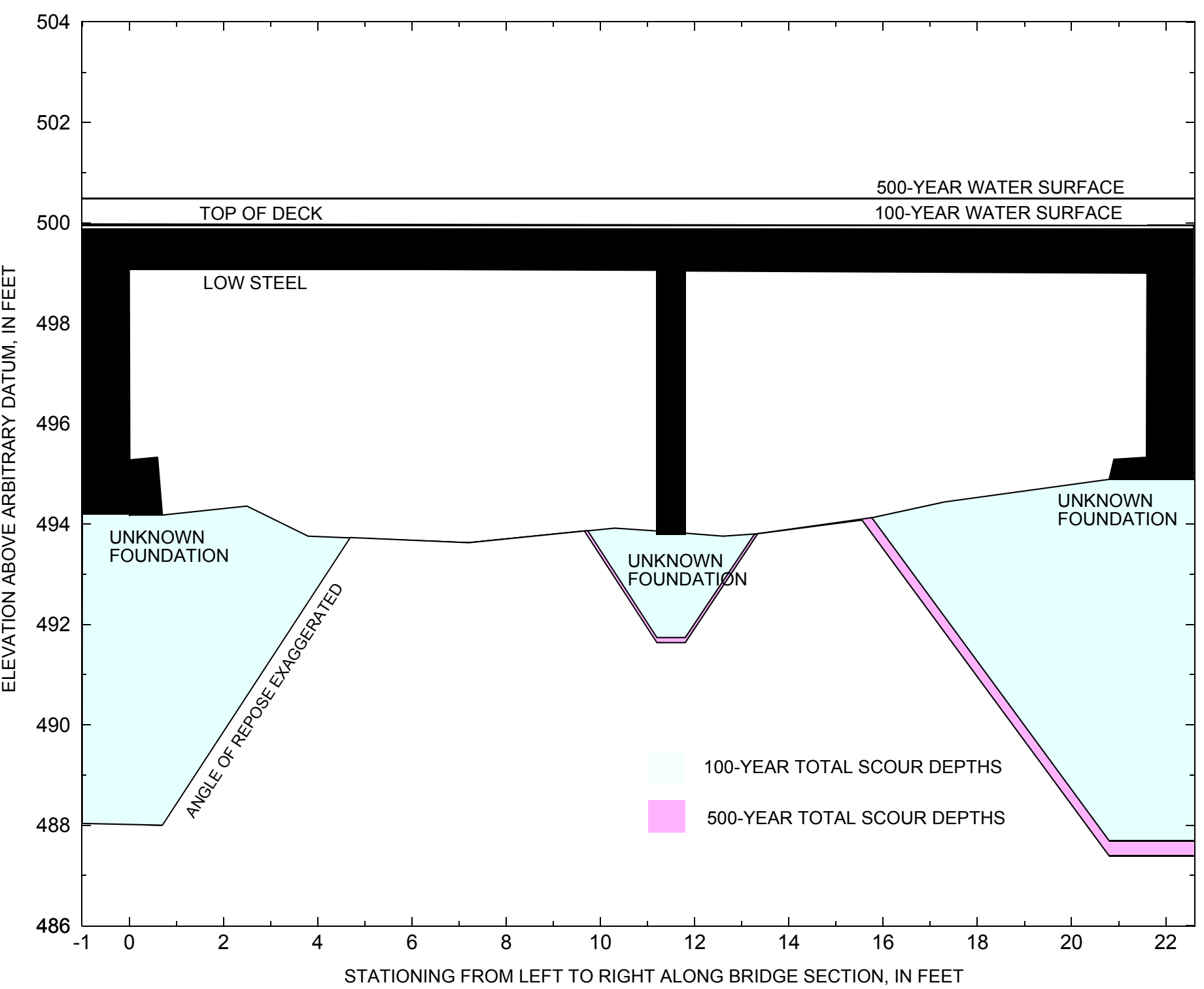

Figure 8. Scour elevations for the 100- and 500-year discharges at structure STRATH00180016 on Town Highway 18, crossing West Branch Ompompanoosuc River, Strafford, Vermont. 
Table 1. Remaining footing/pile depth at abutments for the 100-year discharge at structure STRATH00180016 on Town Highway 18 , crossing the West Branch Ompompanoosuc River, Strafford, Vermont.

[VTAOT, Vermont Agency of Transportation; --,no data]

\begin{tabular}{|c|c|c|c|c|c|c|c|c|c|c|c|}
\hline Description & Station $^{1}$ & $\begin{array}{l}\text { VTAOT } \\
\text { minimum } \\
\text { low-chord } \\
\text { elevation } \\
\text { (feet) }\end{array}$ & $\begin{array}{c}\text { Surveyed } \\
\text { minimum } \\
\text { low-chord } \\
\text { elevation } \\
\text { (feet) }\end{array}$ & $\begin{array}{c}\text { Bottom of } \\
\text { footing } \\
\text { elevation } \\
\text { (feet) }\end{array}$ & $\begin{array}{c}\text { Channel } \\
\text { elevation at } \\
\text { abutment/ } \\
\text { pier }^{2} \\
\text { (feet) }\end{array}$ & $\begin{array}{l}\text { Contraction } \\
\text { scour depth } \\
\text { (feet) }\end{array}$ & $\begin{array}{l}\text { Abutment } \\
\text { scour } \\
\text { depth } \\
\text { (feet) }\end{array}$ & $\begin{array}{l}\text { Pier } \\
\text { scour } \\
\text { depth } \\
\text { (feet) }\end{array}$ & $\begin{array}{l}\text { Depth of } \\
\text { total scour } \\
\text { (feet) }\end{array}$ & $\begin{array}{c}\text { Elevation of } \\
\text { scour }^{2} \\
\text { (feet) }\end{array}$ & $\begin{array}{c}\text { Remaining } \\
\text { footing/pile } \\
\text { depth } \\
\text { (feet) }\end{array}$ \\
\hline \multicolumn{12}{|c|}{100 -yr. discharge is 1,400 cubic-feet per second } \\
\hline Left abutment & 0.0 & -- & 499.1 & -- & 494.2 & 0.0 & 6.2 & -- & 6.2 & 488.0 & -- \\
\hline pier & 11.5 & -- & 499.1 & & 493.8 & 0.0 & -- & 2.1 & 2.1 & 491.7 & -- \\
\hline Right abutment & 21.6 & -- & 499.0 & -- & 494.9 & 0.0 & 7.2 & -- & 7.2 & 487.7 & -- \\
\hline
\end{tabular}

1.Measured along the face of the most constricting side of the bridge.

2.Arbitrary datum for this study.

Table 2. Remaining footing/pile depth at abutments for the 500-year discharge at structure STRATH00180016 on Town Highway 18 , crossing the West Branch Ompompanoosuc River, Strafford, Vermont.

[VTAOT, Vermont Agency of Transportation; --, no data]

\begin{tabular}{|c|c|c|c|c|c|c|c|c|c|c|c|}
\hline Description & Station $^{1}$ & $\begin{array}{l}\text { VTAOT } \\
\text { minimum } \\
\text { low-chord } \\
\text { elevation } \\
\text { (feet) }\end{array}$ & $\begin{array}{c}\text { Surveyed } \\
\text { minimum } \\
\text { low-chord } \\
\text { elevation } \\
\text { (feet) }\end{array}$ & $\begin{array}{c}\text { Bottom of } \\
\text { footing } \\
\text { elevation } \\
\text { (feet) }\end{array}$ & $\begin{array}{c}\text { Channel } \\
\text { elevation at } \\
\text { abutment/ } \\
\text { pier }^{2} \\
\text { (feet) }\end{array}$ & $\begin{array}{l}\text { Contraction } \\
\text { scour depth } \\
\text { (feet) }\end{array}$ & $\begin{array}{l}\text { Abutment } \\
\text { scour } \\
\text { depth } \\
\text { (feet) }\end{array}$ & $\begin{array}{l}\text { Pier } \\
\text { scour } \\
\text { depth } \\
\text { (feet) }\end{array}$ & $\begin{array}{l}\text { Depth of } \\
\text { total scour } \\
\text { (feet) }\end{array}$ & $\begin{array}{c}\text { Elevation of } \\
\text { scour }^{2} \\
\text { (feet) }\end{array}$ & $\begin{array}{c}\text { Remaining } \\
\text { footing/pile } \\
\text { depth } \\
\text { (feet) }\end{array}$ \\
\hline \multicolumn{12}{|c|}{500 -yr. discharge is 1,900 cubic-feet per second } \\
\hline Left abutment & 0.0 & -- & 499.1 & -- & 494.2 & 0.0 & 5.7 & -- & 5.7 & 488.5 & -- \\
\hline pier & 11.5 & -- & 499.1 & & 493.8 & 0.0 & -- & 2.2 & 2.2 & 491.6 & -- \\
\hline Right abutment & 21.6 & -- & 499.0 & -- & 494.9 & 0.0 & 7.5 & -- & 7.5 & 487.4 & -- \\
\hline
\end{tabular}

1.Measured along the face of the most constricting side of the bridge.

2.Arbitrary datum for this study. 


\section{SELECTED REFERENCES}

Arcement, G.J., Jr., and Schneider, V.R., 1989, Guide for selecting Manning's roughness coefficients for natural channels and flood plains: U.S. Geological Survey Water-Supply Paper 2339, 38 p.

Barnes, H.H., Jr., 1967, Roughness characteristics of natural channels: U.S. Geological Survey Water-Supply Paper 1849,213 p.

Benson, M. A., 1962, Factors Influencing the Occurrence of Floods in a Humid Region of Diverse Terrain: U.S. Geological Survey WaterSupply Paper 1580-B, 64 p.

Brown, S.A. and Clyde, E.S., 1989, Design of riprap revetment: Federal Highway Administration Hydraulic Engineering Circular No. 11, Publication FHWA-IP-89-016, 156 p.

Federal Highway Administration, 1983, Runoff estimates for small watersheds and development of sound design: Federal Highway Administration Report FHWA-RD-77-158.

Federal Highway Administration, 1993, Stream Stability and Scour at Highway Bridges: Participant Workbook: Federal Highway Administration Report FHWA-HI-91-011.

Froehlich, D.C., 1989, Local scour at bridge abutments in Ports, M.A., ed., Hydraulic Engineering--Proceedings of the 1989 National Conference on Hydraulic Engineering: New York, American Society of Civil Engineers, p. 13-18.

Hayes, D.C.,1993, Site selection and collection of bridge-scour data in Delaware, Maryland, and Virginia: U.S. Geological Survey WaterResources Investigation Report 93-4017, 23 p.

Interagency Advisory Committee on Water Data, 1982, Guidelines for determining flood flow frequency: U.S. Geological Survey, Bulletin 17B of the Hydrology Subcommittee, 190 p.

Johnson, C.G. and Tasker, G.D.,1974, Progress report on flood magnitude and frequency of Vermont streams: U.S. Geological Survey OpenFile Report 74-130, 37 p.

Lagasse, P.F., Schall, J.D., Johnson, F., Richardson, E.V., Chang, F., 1995, Stream Stability at Highway Structures: Federal Highway Administration Hydraulic Engineering Circular No. 20, Publication FHWA-IP-90-014, 144 p.

Laursen, E.M., 1960, Scour at bridge crossings: Journal of the Hydraulics Division, American Society of Civil Engineers, v. 86, no. HY2, p. 39-53.

Potter, W. D., 1957a, Peak rates of runoff in the Adirondack, White Mountains, and Maine woods area, Bureau of Public Roads

Potter, W. D., 1957b, Peak rates of runoff in the New England Hill and Lowland area, Bureau of Public Roads

Richardson, E.V. and Davis, S.R., 1995, Evaluating scour at bridges: Federal Highway Administration Hydraulic Engineering Circular No. 18, Publication FHWA-IP-90-017, 204 p.

Richardson, E.V., Simons, D.B., and Julien, P.Y., 1990, Highways in the river environment: Federal Highway Administration Publication FHWA-HI-90-016.

Ritter, D.F., 1984, Process Geomorphology: W.C. Brown Co., Debuque, Iowa, 603 p.

Shearman, J.O., 1990, User's manual for WSPRO--a computer model for water surface profile computations: Federal Highway Administration Publication FHWA-IP-89-027, 187 p.

Shearman, J.O., Kirby, W.H., Schneider, V.R., and Flippo, H.N., 1986, Bridge waterways analysis model; research report: Federal Highway Administration Publication FHWA-RD-86-108, 112 p.

Talbot, A.N., 1887, The determination of water-way for bridges and culverts.

U.S. Geological Survey, 1981, Chelsea, Vermont 7.5 Minute Series quadrangle map: U.S. Geological Survey Topographic Maps, Scale $1: 24,000$. 


\section{APPENDIX A: \\ WSPRO INPUT FILE}




\section{WSPRO INPUT FILE}

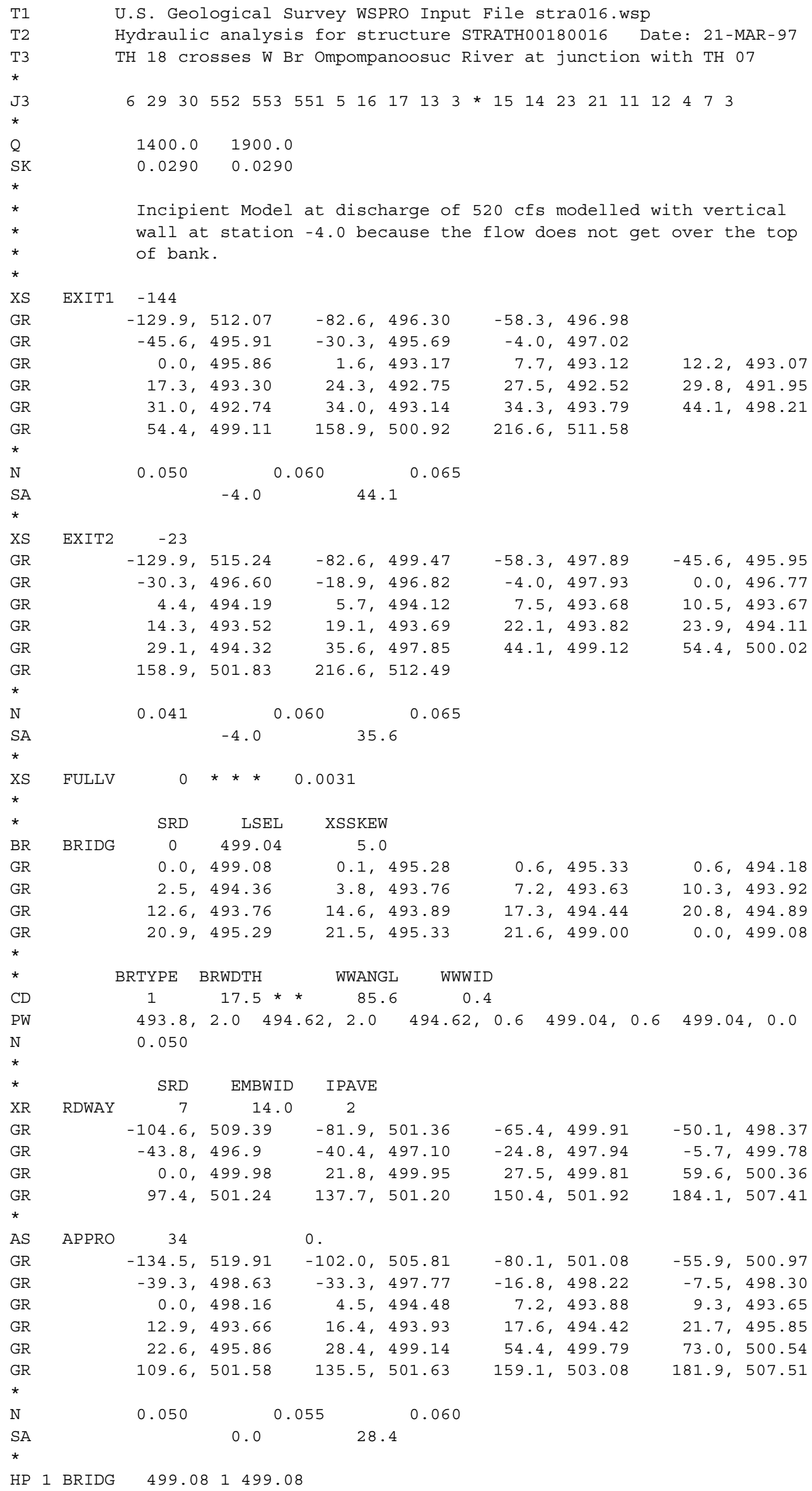


WSPRO INPUT FILE (continued)

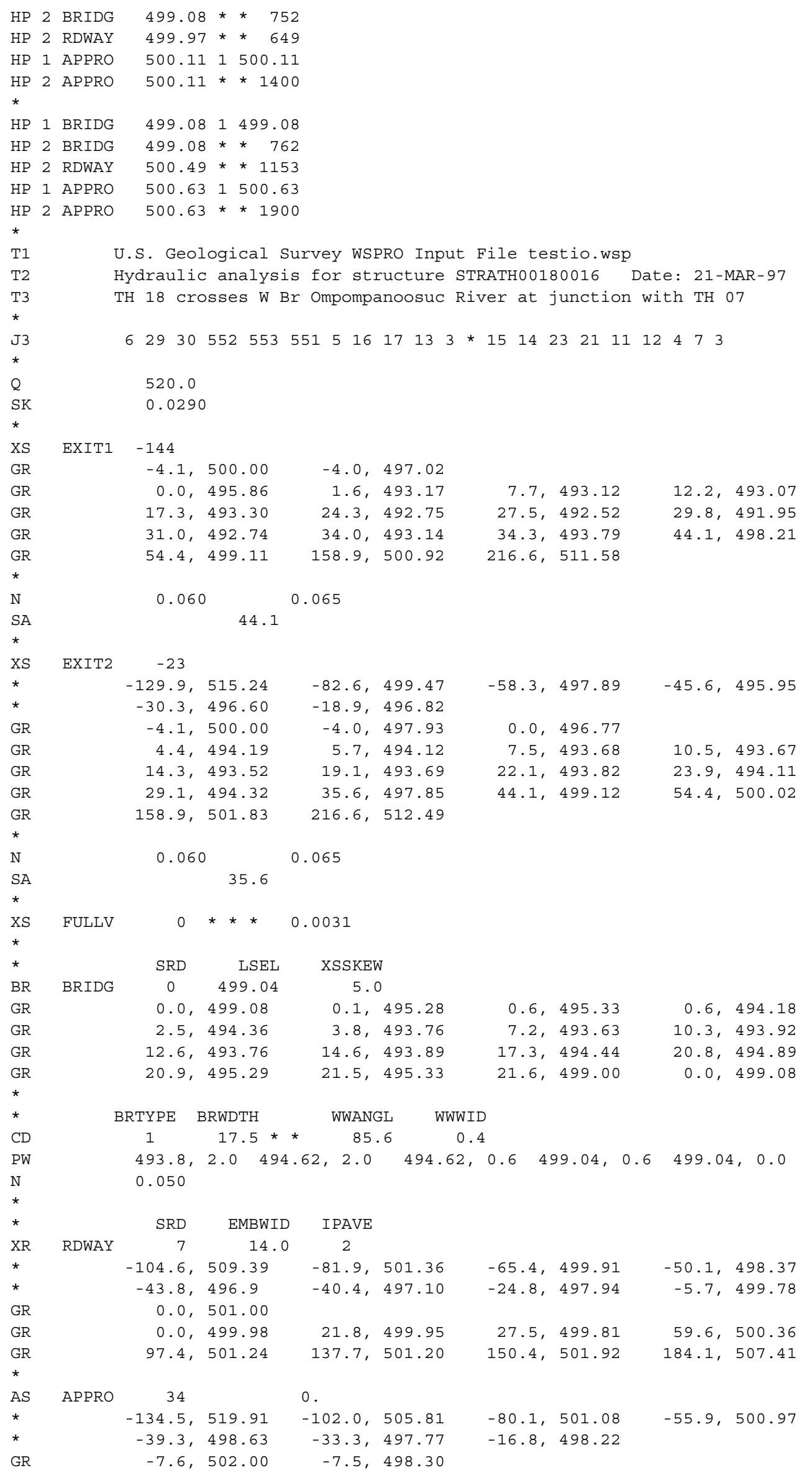




\section{APPENDIX B: \\ WSPRO OUTPUT FILE}




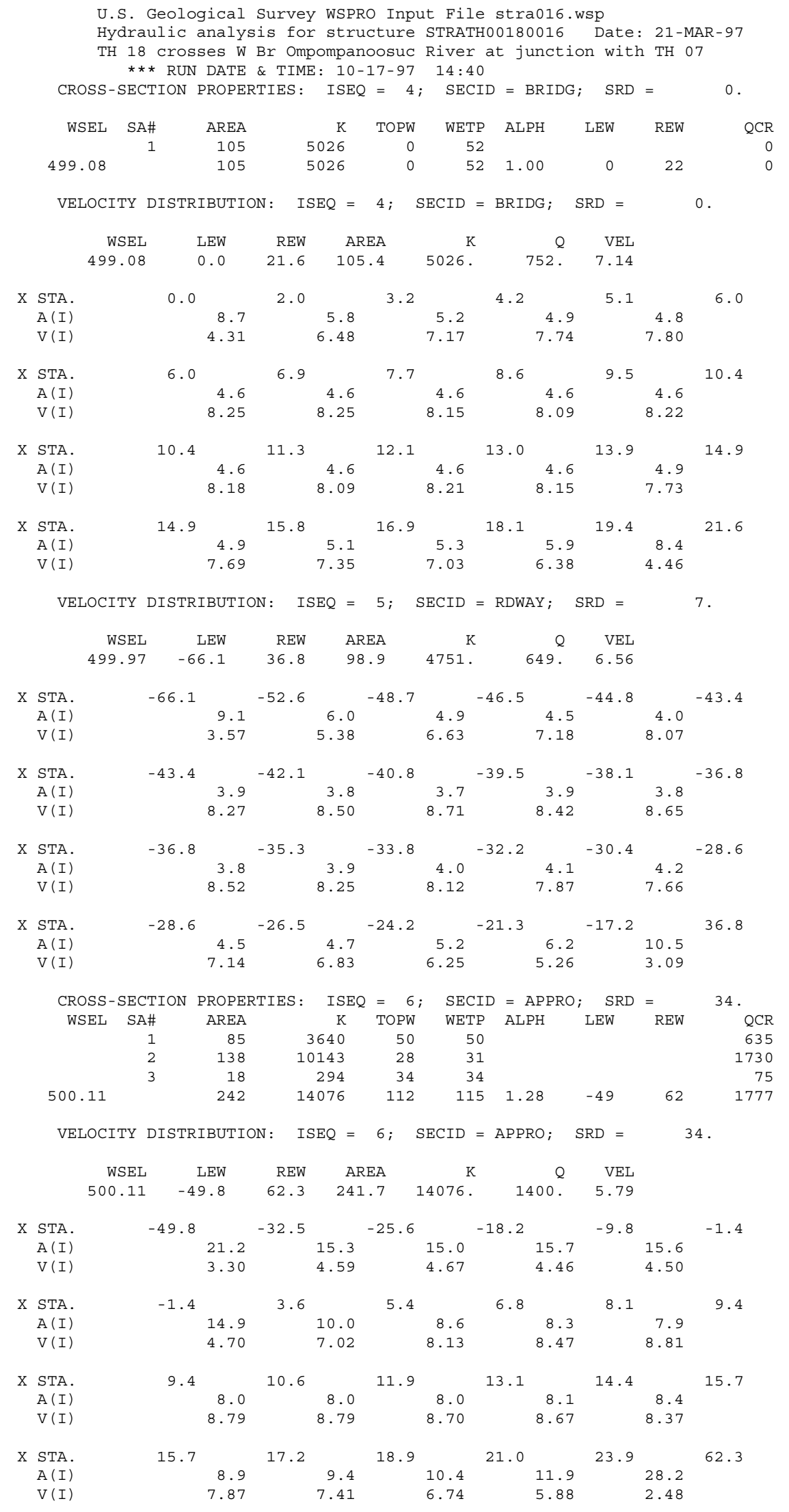


WSPRO OUTPUT FILE (continued)

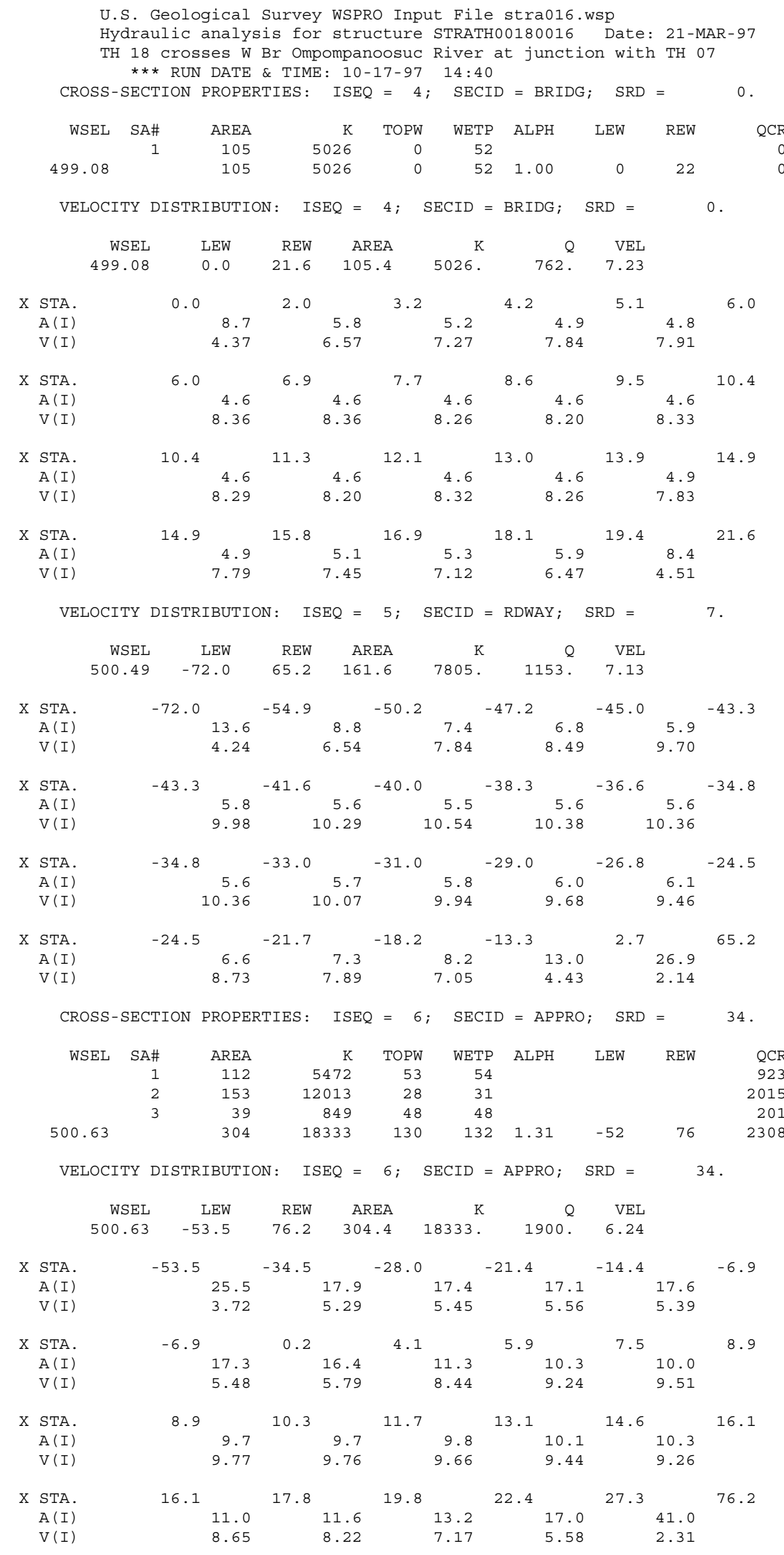


WSPRO OUTPUT FILE (continued)

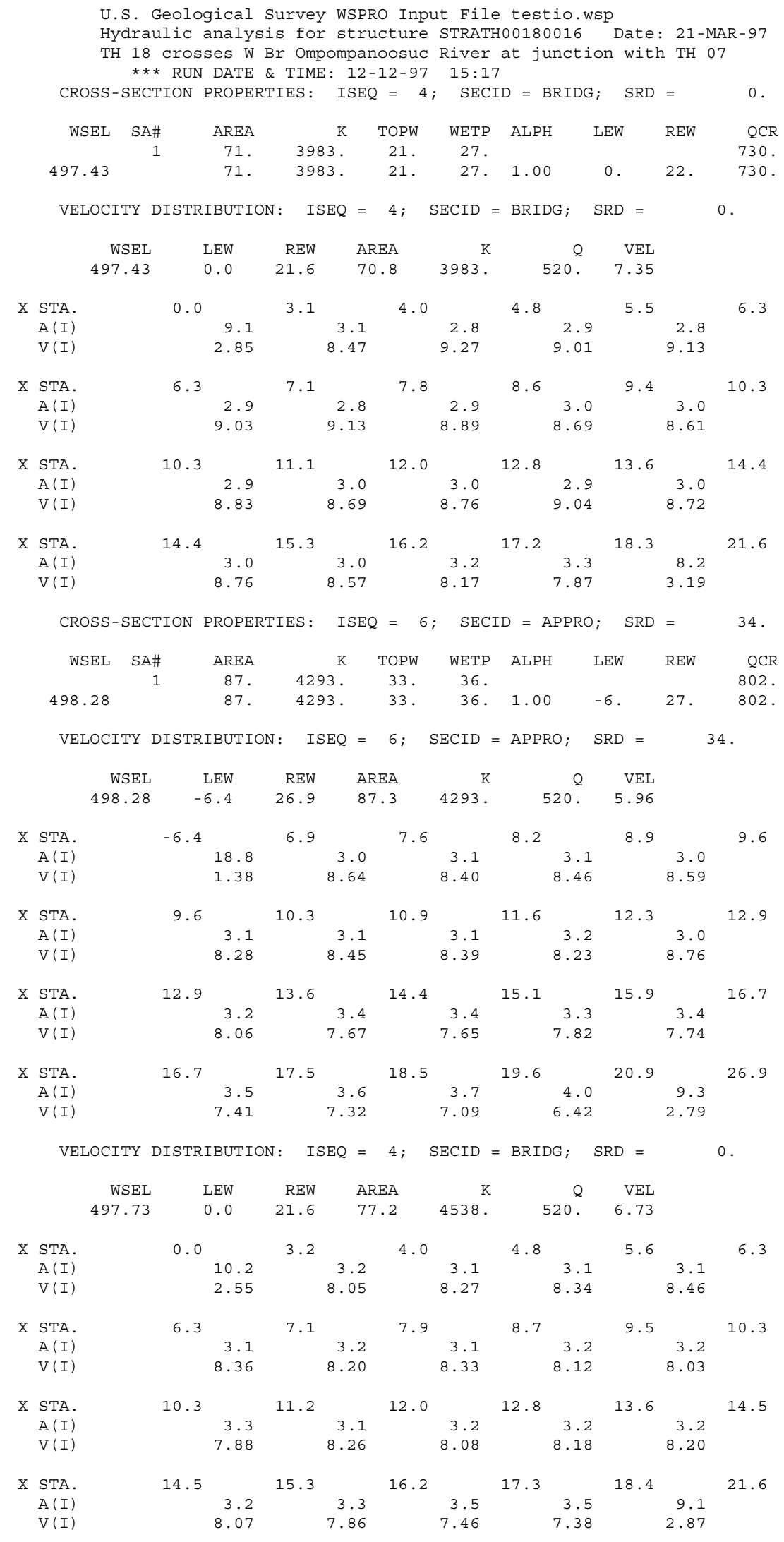


WSPRO OUTPUT FILE (continued)

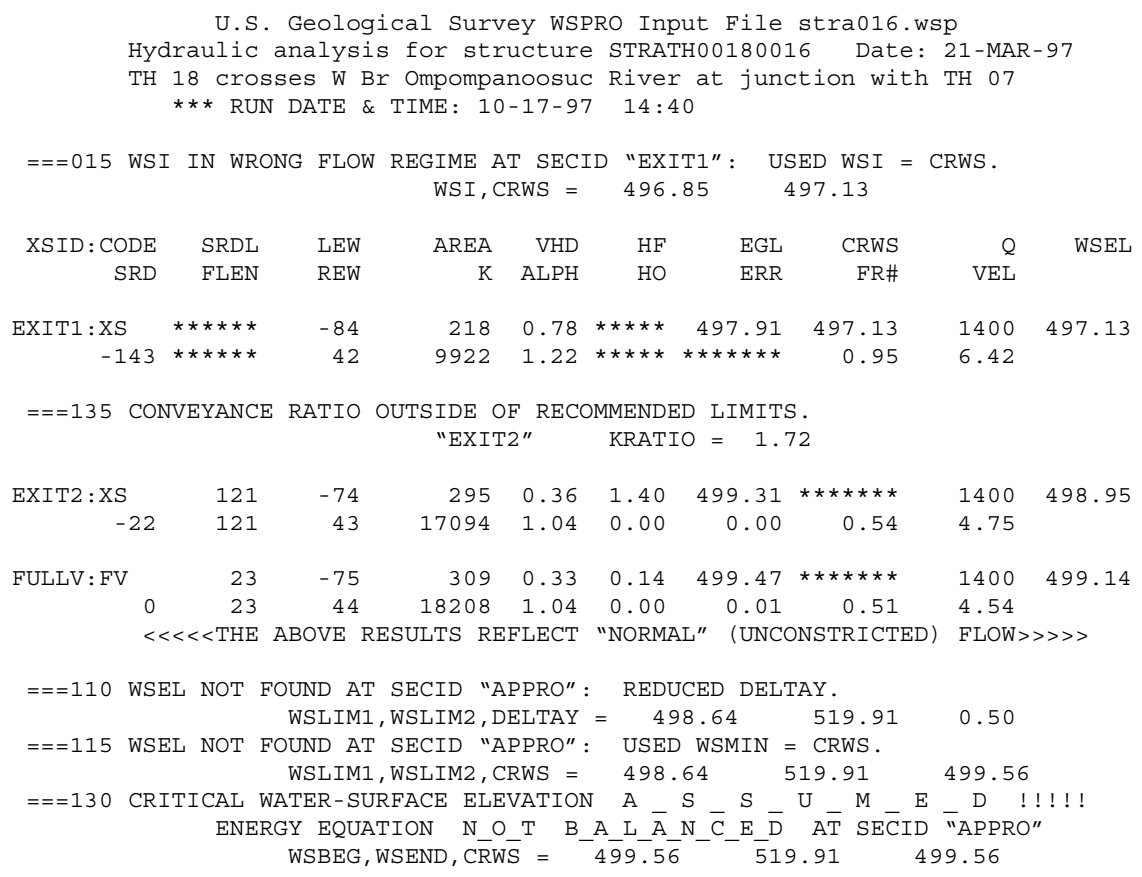

SECOND USER DEFINED TABLE.

$\begin{array}{lcrrrrrrrr}\text { XSID :CODE } & \text { CRWS } & \text { FR\# } & \text { YMIN } & \text { YMAX } & \text { HF } & \text { HO } & \text { VHD } & \text { EGL } & \text { WSEL } \\ \text { EXIT1:XS } & 497.13 & 0.95 & 491.95 & 512.07 * * * * * * * * * * & 0.78 & 497.91 & 497.13 \\ \text { EXIT2:XS } & * * * * * * * * & 0.54 & 493.52 & 515.24 & 1.40 & 0.00 & 0.36 & 499.31 & 498.95 \\ \text { FULLV:FV } & * * * * * * * * & 0.51 & 493.59 & 515.31 & 0.14 & 0.00 & 0.33 & 499.47 & 499.14 \\ \text { BRIDG :BR } & 497.64 & 0.61 & 493.63 & 499.08 * * * * * * * * * * * & 0.86 & 499.94 & 499.08 \\ \text { RDWAY:RG } & * * * * * * * * * * * * * * & 496.90 & 509.39 & 0.20 * * * * * * & 0.67 & 500.58 & 499.97 \\ \text { APPRO:AS } & 499.56 & 0.79 & 493.65 & 519.91 & 0.30 & 0.00 & 0.67 & 500.78 & 500.11\end{array}$


WSPRO OUTPUT FILE (continued)

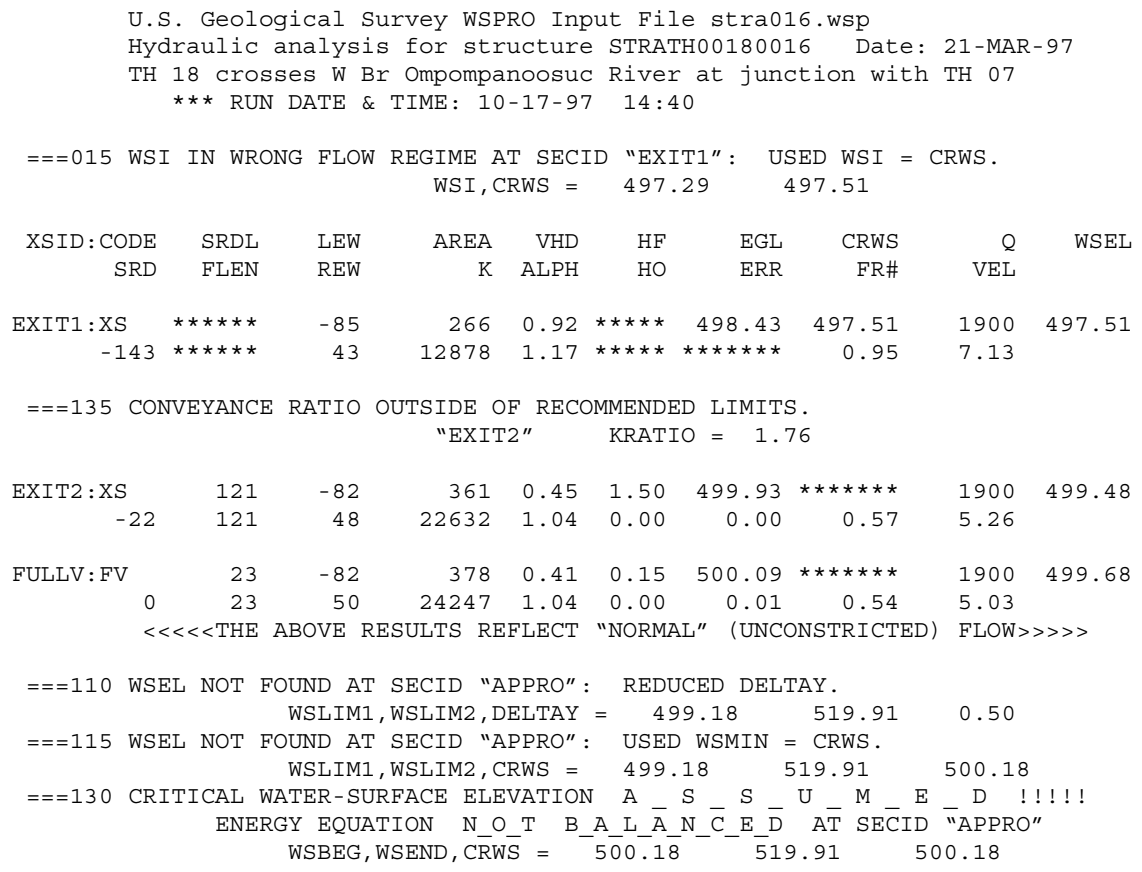

FIRST USER DEFINED TABLE.

$\begin{array}{lrrrrrrrr}\text { XSID : CODE } & \text { SRD } & \text { LEW } & \text { REW } & Q & \text { K } & \text { AREA } & \text { VEL } & \text { WSEL } \\ \text { EXIT1 }: \text { XS } & -144 . & -86 . & 43 . & 1900 . & 12878 . & 266 . & 7.13 & 497.51 \\ \text { EXIT2 }: \text { XS } & -23 . & -83 . & 48 . & 1900 . & 22632 . & 361 . & 5.26 & 499.48 \\ \text { FULLV }: \text { FV } & 0 . & -83 . & 50 . & 1900 . & 24247 . & 378 . & 5.03 & 499.68 \\ \text { BRIDG }: \text { BR } & 0 . & 0 . & 22 . & 762 . & 5026 . & 101 . & 7.54 & 499.08 \\ \text { RDWAY : RG } & 7 . * * * * * * * & 972 . & 1153 . * * * * * * * * * * * * * * * * & 2.00 & 500.49 \\ \text { APPRO : AS } & 34 . & -53 . & 76 . & 1900 . & 18332 . & 304 . & 6.24 & 500.63\end{array}$

SECOND USER DEFINED TABLE.

$\begin{array}{lcrrrrrrrr}\text { XSID:CODE } & \text { CRWS } & \text { FR\# } & \text { YMIN } & \text { YMAX } & \text { HF } & \text { HO } & \text { VHD } & \text { EGL } & \text { WSEL } \\ \text { EXIT1:XS } & 497.51 & 0.95 & 491.95 & 512.07 * * * * * * * * * * * & 0.92 & 498.43 & 497.51 \\ \text { EXIT2:XS } & * * * * * * * * & 0.57 & 493.52 & 515.24 & 1.50 & 0.00 & 0.45 & 499.93 & 499.48 \\ \text { FULLV:FV } & * * * * * * * * & 0.54 & 493.59 & 515.31 & 0.15 & 0.00 & 0.41 & 500.09 & 499.68 \\ \text { BRIDG:BR } & 497.65 & 0.61 & 493.63 & 499.08 * * * * * * * * * * * & 0.88 & 499.96 & 499.08 \\ \text { RDWAY:RG } & * * * * * * * * * * * * * * * * & 496.90 & 509.39 & 0.21 * * * * * * & 0.80 & 501.21 & 500.49 \\ \text { APPRO:AS } & 500.18 & 0.82 & 493.65 & 519.91 & 0.37 & 0.00 & 0.80 & 501.43 & 500.63\end{array}$


WSPRO OUTPUT FILE (continued)

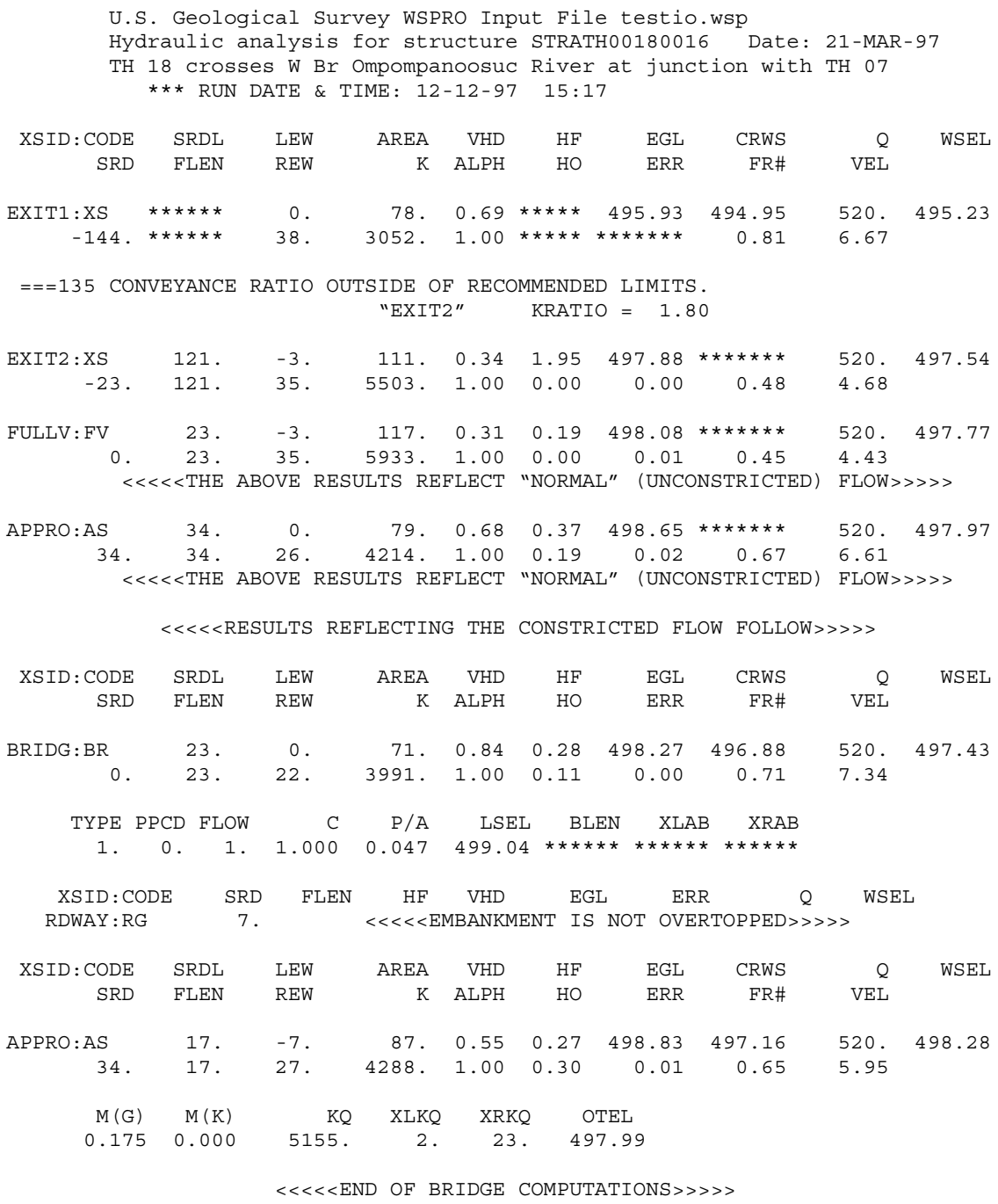

FIRST USER DEFINED TABLE.

\begin{tabular}{|c|c|c|c|c|c|c|c|c|}
\hline XSID : CODE & SRD & LEW & REW & $Q$ & K & AREA & VEL & WSEL \\
\hline EXIT1:XS & -144 & 0 . & 38. & 520. & 3052 . & 78. & 6.67 & 495.23 \\
\hline EXIT2: XS & -23 & -3 . & 35. & 520. & 5503. & 111. & 4.68 & 497.54 \\
\hline FULLV : FV & 0 . & -3 . & 35. & 520. & 5933. & 117. & 4.43 & 497.77 \\
\hline BRIDG : BR & 0 . & 0 . & 22 . & 520. & 3991. & 71. & 7.34 & 497.43 \\
\hline RDWAY : RG & \multicolumn{3}{|c|}{ 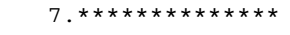 } & \multicolumn{3}{|c|}{ 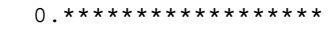 } & \multicolumn{2}{|c|}{$2.00 * \star * \star * * * *$} \\
\hline APPRO : AS & 34. & -7 & 27. & 520. & 4288. & 87. & 5.95 & 498.28 \\
\hline XSID : CODE & XLKQ & $\mathrm{XRKQ}$ & & & & & & \\
\hline APPRO : AS & 2 . & 23. & 515 & & & & & \\
\hline
\end{tabular}

SECOND USER DEFINED TABLE.

$\begin{array}{lrrrrrrrrr}\text { XSID : CODE } & \text { CRWS } & \text { FR\# } & \text { YMIN } & \text { YMAX } & \text { HF } & \text { HO } & \text { VHD } & \text { EGL } & \text { WSEL } \\ \text { EXIT1:XS } & 494.95 & 0.81 & 491.95 & 511.58 * * * * * * * * * * * & 0.69 & 495.93 & 495.23 \\ \text { EXIT2:XS } & * * * * * * * & 0.48 & 493.52 & 512.49 & 1.95 & 0.00 & 0.34 & 497.88 & 497.54 \\ \text { FULLV:FV } & * * * * * * * * & 0.45 & 493.59 & 512.56 & 0.19 & 0.00 & 0.31 & 498.08 & 497.77 \\ \text { BRIDG: BR } & 496.88 & 0.71 & 493.63 & 499.08 & 0.28 & 0.11 & 0.84 & 498.27 & 497.43 \\ \text { RDWAY : RG } & * * * * * * * * * * * * * * * * & 499.81 & 507.41 * * * * * * * * * * * * * * * * * * * * * * * * * * * * * * \\ \text { APPRO:AS } & 497.16 & 0.65 & 493.65 & 507.51 & 0.27 & 0.30 & 0.55 & 498.83 & 498.28\end{array}$




\section{APPENDIX C:}

\section{BED-MATERIAL PARTICLE-SIZE DISTRIBUTION}




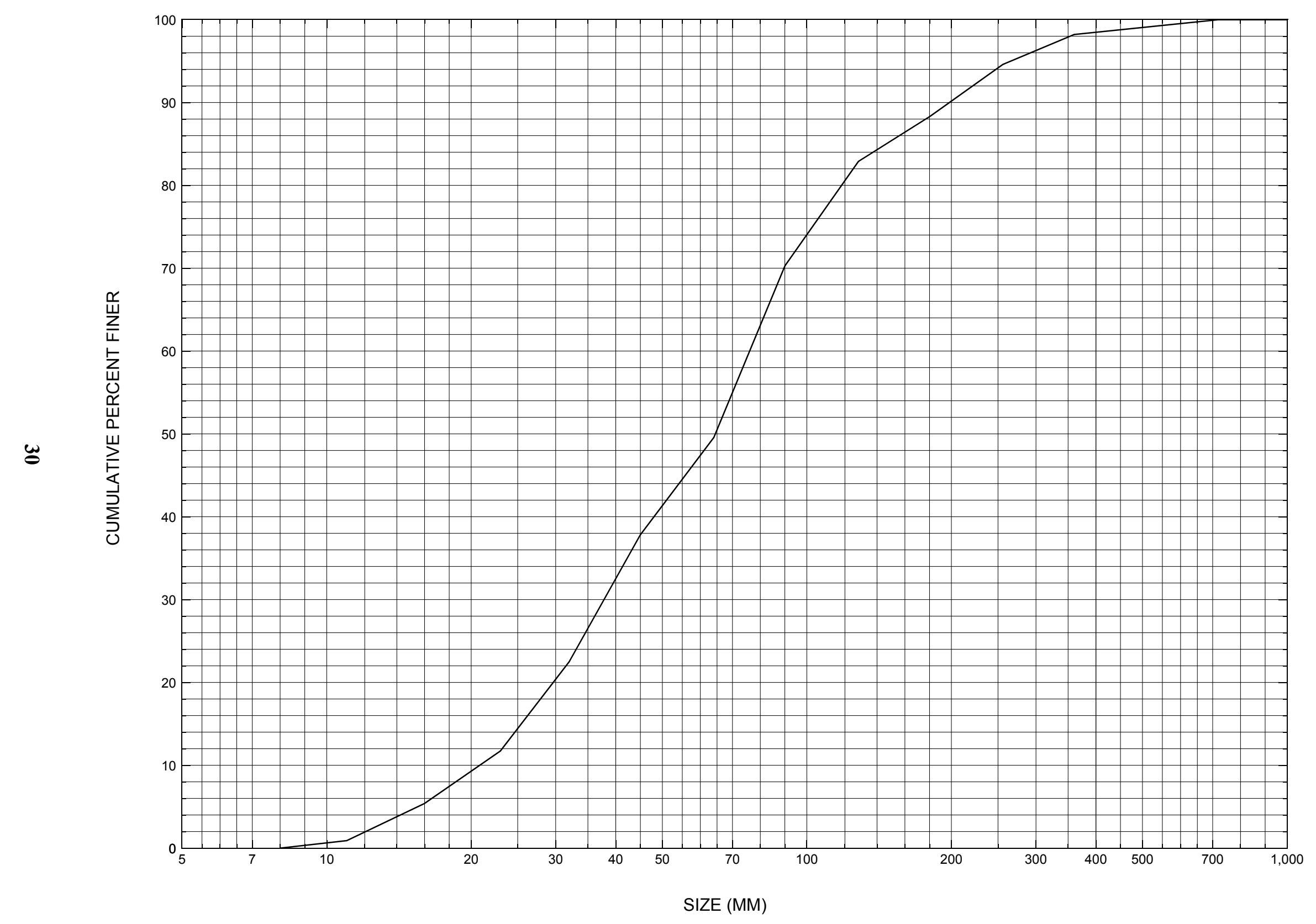

Appendix C. Bed material particle-size distribution for a pebble count in the channel approach of structure STRATH00180016, in Strafford, Vermont. 


\section{APPENDIX D: \\ HISTORICAL DATA FORM}




\section{Structure Number STRATH00180016}

\section{General Location Descriptive}

Data collected by (First Initial, Full last name) $\mathbf{E}$. BOEHMLER

Date $(M M / D D / Y Y) \_\mathbf{0 3} / \underline{23} / \underline{95}$

Highway District Number (I - 2; nn) 04

Town (FIPS place code; I - 4; nnnnn) $\mathbf{7 0 6 7 5}$

Waterway (I - 6) West Branch Ompompanoosuc River

Route Number TH018

Topographic Map Chelsea

Latitude (I - 16; nnnn.n) $\mathbf{4 3 5 4 0}$
County (FIPS county code; I - 3; nnn)

Mile marker (I - 11; nnn.nnn) $\mathbf{0 0 0 0 0 0}$

Road Name (I - 7): -

Vicinity (I - 9)@JCT W CL3 TH7

Hydrologic Unit Code: $\mathbf{0 1 0 8 0 1 0 3}$

Longitude (i - 17; nnnnn.n) $\mathbf{7 2 2 3 5}$

\section{Select Federal Inventory Codes}

FHWA Structure Number (I - 8) 10091000160910

Maintenance responsibility $(I-21 ; n n) \quad \mathbf{0 3} \quad$ Maximum span length $(I-48 ; n n n n) \underline{\mathbf{0 0 1 1}}$

Year built (I - 27; YYYY) 1991

Structure length (I - 49; nnnnnn) $\underline{\mathbf{0 0 0 0 3 5}}$

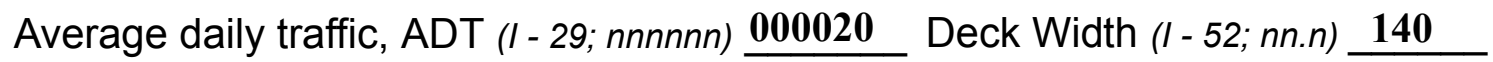

Year of ADT (I - 30; YY) $\underline{\mathbf{9 1}}$

Channel \& Protection $(I-61 ; n) \underline{\mathbf{6}}$

Opening skew to Roadway $(I-34 ; n n) \quad \mathbf{0 0}$

Waterway adequacy $(I-71 ; n)$

Operational status $(I-41 ; X) \quad \mathbf{B}$

Underwater Inspection Frequency $(I-92 B ; X Y Y) \_\mathbf{N}$

Structure type (I- 43; nnn) $\mathbf{4 0 2}$

Year Reconstructed (I - 106) $\mathbf{0 0 0 0}$

Approach span structure type (I - 44; nnn) $\mathbf{0 0 0}$ Clear span (nnn.n ft) _ _

Number of spans (I - 45; nnn) $\underline{\mathbf{0 0 2}}$

Vertical clearance from streambed (nnn.n ft) $\underline{\mathbf{0 0 5 . 0}}$

Number of approach spans (I - 46; nnnn) $\mathbf{0 0 0 0}$

Waterway of full opening $\left(n n n . n \mathrm{ft}^{2}\right)$ -

Comments:

The structural inspection report dated 6/13/94 indicates the structure is a two span railroad rail stringer type bridge with a timber deck. The abutments are concrete and reported in "like new" condition. The footings of each abutment are indicated as exposed at the surface but are not undermined. Each abutment has stone fill protection in front of the wall. The pier consists of a concrete footing on four pressure treated timber columns with diagonal pressure treated wooden plank bracing. Overall the pier (bent) is noted in fairly good condition. The streambed material is reported as consisting of stone and gravel with a few randomly distributed boulders. (Continued, page 34) 


\section{Bridge Hydrologic Data}

Is there hydrologic data available? $\underline{\mathbf{N}}$ if No, type ctrl-n $h \quad$ VTAOT Drainage area $\left(m i^{2}\right)$ : -

Terrain character:

Stream character \& type: -

Streambed material:

Discharge Data (cfs):

$$
\begin{aligned}
& Q_{2.33}- \\
& Q_{50}-
\end{aligned}
$$

Record flood date $(M M / D D / Y Y)$ :

Estimated Discharge (cfs): Ice conditions (Heavy, Moderate, Light) : -

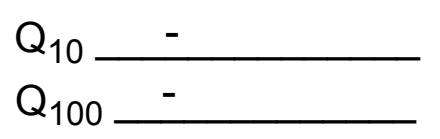

$$
\begin{aligned}
& Q_{25}- \\
& Q_{500}-
\end{aligned}
$$

Water surface elevation $(f t):-$

The stage increases to maximum highwater elevation (Rapidly, Not rapidly):

The stream response is (Flashy, Not flashy):

Describe any significant site conditions upstream or downstream that may influence the stream's stage: -

Watershed storage area (in percent): _ _ \%

The watershed storage area is: - (1-mainly at the headwaters; 2- uniformly distributed; 3-immediatly upstream oi the site)

Water Surface Elevation Estimates for Existing Structure:

\begin{tabular}{|l|l|l|l|l|l|}
\hline Peak discharge frequency & $Q_{2.33}$ & $Q_{10}$ & $Q_{25}$ & $Q_{50}$ & $Q_{100}$ \\
Water surface elevation (ft)) & - & - & - & - & - \\
Velocity (ft/sec) & - & - & - & - & - \\
\hline
\end{tabular}

Long term stream bed changes: -

Is the roadway overtopped below the $\mathrm{Q}_{100}$ ? (Yes, No, Unknown): $\mathbf{U} \quad$ Frequency: Relief Elevation (ft): Discharge over roadway at $Q_{100}\left(f^{3} / \mathrm{sec}\right)$ :

Are there other structures nearby? (Yes, No, Unknown): $\underline{\mathbf{U}}$ Upstream distance (miles): Town: If No or Unknown, type ctrl-n os Highway No. : Structure No. : Year Built:

Clear span (ft): Clear Height $(f t)$ : Full Waterway $\left(f^{2}\right)$ : 
Downstream distance (miles): Town: Year Built:

Highway No. : Structure No. : Structure Type:

Clear span (ft): Clear Height $(f t)$ : Full Waterway $\left(f^{2}\right)$ :

Comments:

Channel scour is noted as not evident. Minor bank erosion is mentioned. Furthermore, debris accumulation is noted as minor. The riprap mentioned in the report is noted as natural stone and boulders.

\section{USGS Watershed Data}

Watershed Hydrographic Data

Drainage area $(D A) \underline{6.28}$

Watershed storage (ST) $\mathrm{mi}^{2}$ Lake/pond/swamp area 0 $\mathrm{mi}^{2}$

Bridge site elevation 1140

Main channel length 4.94 $\mathrm{ft}$ $\%$ $10 \%$ channel length elevation $\mathbf{1 1 2 0}$ mi Headwater elevation 2380 $\mathrm{ft}$

Main channel slope (S)

(S) 248.31 $\mathrm{ft} / \mathrm{mi}$

Watershed Precipitation Data

Average site precipitation in Average headwater precipitation in

Maximum 2yr-24hr precipitation event $(124,2)$ in

Average seasonal snowfall (Sn) $\mathrm{ft}$ 


\section{Bridge Plan Data}

Are plans available? $\mathbf{N} \quad$ If no, type ctrl-n pl Date issued for construction (MM / YYYY):

Project Number

Minimum channel bed elevation:

Low superstructure elevation: USLAB DSLAB USRAB DSRAB Benchmark location description:

There is no benchmark information available.

Reference Point (MSL, Arbitrary, Other):

Datum (NAD27, NAD83, Other):

Foundation Type: 4

If 1: Footing Thickness

If 2: Pile Type:

If 3: Footing bottom elevation:

Is boring information available? $\mathbf{N}$

Foundation Material Type: $\mathbf{3}$

(1-Spreadfooting; 2-Pile; 3- Gravity; 4-Unknown)

Footing bottom elevation: -

Briefly describe material at foundation bottom elevation or around piles:

There is no foundation material information available.

Comments:

There are no bridge plans available. 


\section{Cross-sectional Data}

Is cross-sectional data available? $\mathbf{N}$ If no, type ctrl-n xs

Source (FEMA, VTAOT, Other)? -

Comments: There is no cross-section information available.

\begin{tabular}{|l|l|l|l|l|l|l|l|l|l|l|l|}
\hline Station & - & - & - & - & - & - & - & - & - & - & - \\
\hline Feature & - & - & - & - & - & - & - & - & - & - & - \\
\hline $\begin{array}{l}\text { Low cord } \\
\text { elevation }\end{array}$ & - & - & - & - & - & - & - & - & - & - & - \\
\hline $\begin{array}{l}\text { Bed } \\
\text { elevation }\end{array}$ & - & - & - & - & - & - & - & - & - & - & - \\
\hline $\begin{array}{l}\text { Low cord to } \\
\text { bed length }\end{array}$ & - & - & - & - & - & - & - & - & - & - & - \\
\hline Station & - & - & - & - & - & - & - & - & - & - & - \\
\hline Feature & - & - & - & - & - & - & - & - & - & - & - \\
\hline $\begin{array}{l}\text { Low cord } \\
\text { elevation }\end{array}$ & - & - & - & - & - & - & - & - & - & - & - \\
\hline $\begin{array}{l}\text { Bed } \\
\text { elevation }\end{array}$ & - & - & - & - & - & - & - & - & - & - & - \\
\hline $\begin{array}{l}\text { Low cord to } \\
\text { bed length }\end{array}$ & - & - & - & - & - & - & - & - & - & - & - \\
\hline
\end{tabular}

Source (FEMA, VTAOT, Other)?

Comments: There is no cross-section information available.

\begin{tabular}{|l|l|l|l|l|l|l|l|l|l|l|l|}
\hline Station & - & - & - & - & - & - & - & - & - & - & - \\
\hline Feature & - & - & - & - & - & - & - & - & - & - & - \\
\hline $\begin{array}{l}\text { Low cord } \\
\text { elevation }\end{array}$ & - & - & - & - & - & - & - & - & - & - & - \\
\hline $\begin{array}{l}\text { Bed } \\
\text { elevation }\end{array}$ & - & - & - & - & - & - & - & - & - & - & - \\
\hline $\begin{array}{l}\text { Low cord to } \\
\text { bed length }\end{array}$ & - & - & - & - & - & - & - & - & - & - & - \\
\hline Station & - & - & - & - & - & - & - & - & - & - & - \\
\hline Feature & - & - & - & - & - & - & - & - & - & - & - \\
\hline $\begin{array}{l}\text { Low cord } \\
\text { elevation }\end{array}$ & - & - & - & - & - & - & - & - & - & - & - \\
\hline $\begin{array}{l}\text { Bed } \\
\text { elevation }\end{array}$ & - & - & - & - & - & - & - & - & - & - & - \\
\hline $\begin{array}{l}\text { Low cord to } \\
\text { bed length }\end{array}$ & - & - & - & - & - & - & - & - & - & - & - \\
\hline
\end{tabular}




\section{APPENDIX E: \\ LEVEL I DATA FORM}


U. S. Geological Survey

Bridge Field Data Collection and Processing Form

Qa/Qc Check by: RB Date: $4 / 9 / 96$

\section{Structure Number STRATH00180016}

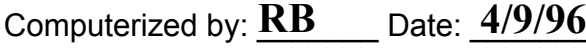

Reviewd by: LKS Date: 12/12/97

\section{A. General Location Descriptive}

1. Data collected by (First Initial, Full last name) M. IVANOFF

Date $(M M / D D / Y Y)$

$10 / 19$

1995

2. Highway District Number $\mathbf{0 4}$

County Orange (0170)

Waterway (I - 6) West Branch Ompompanoosuc River

Route Number $\mathbf{T H 0 1 8}$

3. Descriptive comments:

The bridge is located at the junction of TH 17 and TH 18.
Mile marker $\underline{0}$

Town Strafford (70675)

Road Name -

Hydrologic Unit Code: $\mathbf{0 1 0 8 0 1 0 3}$

\section{B. Bridge Deck Observations}
4. Surface cover... LBUS 6
RBUS 5
LBDS 6
RBDS 6
Overall 6

(2b us,ds,lb,rb: 1- Urban; 2- Suburban; 3- Row crops; 4- Pasture; 5- Shrub- and brushland; 6- Forest; 7- Wetland)
5. Ambient water surface... US 2
UB 2
DS 2
(1- pool; 2- riffle)

6. Bridge structure type 2 (1- single span; 2- multiple span; 3- single arch; 4- multiple arch; 5-cylindrical culvert; 6- box culvert; or 7- other)
7. Bridge length $\mathbf{3 5}$
(feet)
Span length 11
(feet)
Bridge width 14 (feet)

\section{Road approach to bridge:}
8. LB $\underline{1}$ RB $\underline{0}$
( 0 even, 1- lower, 2- higher)
9. LB_2
RB $\underline{2}$
(1-Paved, 2- Not paved)

10. Embankment slope (run / rise in feet / foot)

US left

US right

\begin{tabular}{|c|c|c|c|}
\hline \multicolumn{2}{|c|}{ Protection } & \multirow{2}{*}{ 13.Erosion } & 14.Severity \\
\hline 11.Type & 12.Cond. & $\mathbf{0}$ & $\mathbf{0}$ \\
\hline $\mathbf{0}$ & - & $\mathbf{0}$ & $\mathbf{0}$ \\
\hline $\mathbf{0}$ & - & $\mathbf{0}$ & $\mathbf{0}$ \\
\hline $\mathbf{0}$ & - & $\mathbf{0}$ & $\mathbf{0}$ \\
\hline $\mathbf{0}$ & - & $\mathbf{0}$ & $\mathbf{0}$ \\
\hline
\end{tabular}

Bank protection types: 0- none; 1- < 12 inches,

2- $<36$ inches; $3-<48$ inches;

4- < 60 inches; 5- wall / artificial levee

Bank protection conditions: 1- good; 2- slumped;

3- eroded; 4- failed

Erosion: 0 - none; 1- channel erosion; 2 -

road wash; 3- both; 4- other

Erosion Severity: 0 - none; 1- slight; 2- moderate; 3- severe

\section{Channel approach to bridge (BF):}

15. Angle of approach: 0

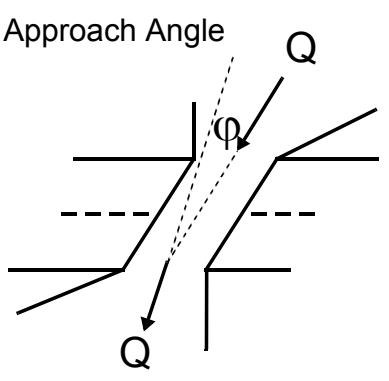

17. Channel impact zone 1:

Where? $(L B, R B)$

Range? feet -

Channel impact zone 2:

Where? $(L B, R B)$

Range? - $\quad$ feet -

(US, UB, DS) to feet Impact Severity: 0- none to very slight; 1- Slight; 2- Moderate; 3- Severe

16. Bridge skew: $\mathbf{0}$ Bridge Skew Angle

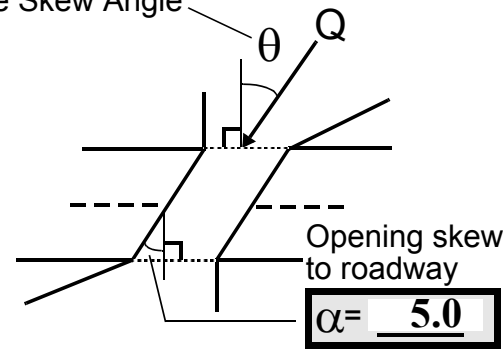

Exist? $\mathbf{N}(Y$ or $N)$

Severity

(US, UB, DS) to -

Exist? $\mathbf{N}(Y$ or $N)$

Severity - 
18. Bridge Type: 1a

1a- Vertical abutments with wingwalls

1 b- Vertical abutments without wingwalls

2- Vertical abutments and wingwalls, sloping embankment Wingwalls perpendicular to abut. face

3- Spill through abutments

4- Sloping embankment, vertical wingwalls and abutments

Wingwall angle less than $90^{\circ}$.

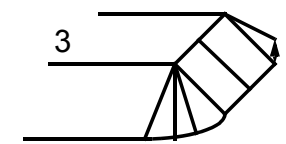

$$
\text { 政 }
$$

19. Bridge Deck Comments (surface cover variations, measured bridge and span lengths, bridge type variations, approach overflow width, etc.)

7. Bridge dimensions are from the VTAOT files. The measured bridge length is $35.4 \mathrm{ft}$ and the bridge span is 21.6 $\mathrm{ft}$. The left span opening from the abutment to the pier is $\mathbf{1 0} \mathrm{ft}$.

\section{Upstream Channel Assessment}

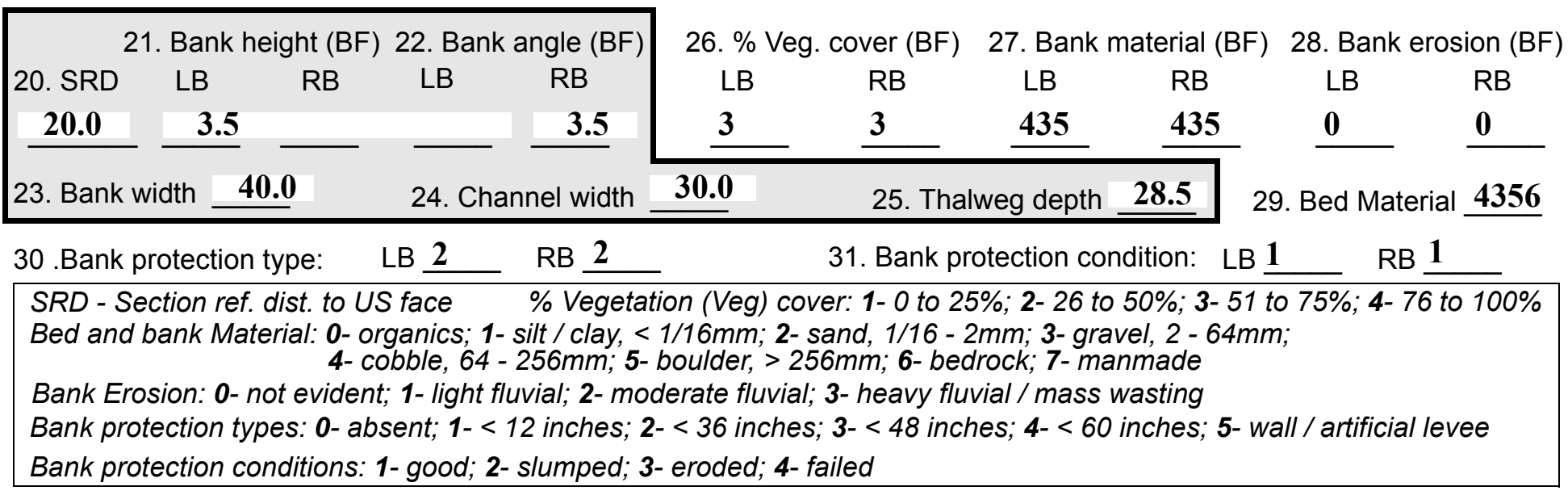

32. Comments (bank material variation, minor inflows, protection extent, etc.):

30. The bank protection is natural bank material that extends beyond $300 \mathrm{ft}$ upstream.

There is bedrock control 108 to $180 \mathrm{ft}$ upstream along the left bank and channel. 
33.Point/Side bar present? $\mathbf{N}(Y$ or $N$. if $N$ type ctrl-n pb)34. Mid-bar distance: -

35. Mid-bar width:

36. Point bar extent: feet (US, UB) to feet (US, UB, DS) positioned $\%$ LB to $\% \mathrm{RB}$

37. Material: -

38. Point or side bar comments (Circle Point or Side; Note additional bars, material variation, status, etc.):

There are no pointbars upstream at this site.

39. Is a cut-bank present? $\underline{\mathbf{N}}$ (Y or if $\mathrm{N}$ type ctrl-n cb)

40. Where? (LB or $R B)$

41. Mid-bank distance: -

42. Cut bank extent: feet (US, UB) to feet (US, UB, DS)

43. Bank damage: ( 1- eroded and/or creep; 2- slip failure; 3- block failure)

44. Cut bank comments (eg. additional cut banks, protection condition, etc.):

There are no cut-banks upstream at this site.

\section{Is channel scour present? $\mathbf{N}$ ( $Y$ or if $N$ type ctrl-n cs)}

47. Scour dimensions: Length Width Depth : 46. Mid-scour distance: -

48. Scour comments (eg. additional scour areas, local scouring process, etc.):

There is no channel scour upstream at this site.

49. Are there major confluences? $\mathbf{Y}$ ( $Y$ or if $N$ type ctrl-n $m c$ )

51. Confluence 1: Distance 208

Confluence 2: Distance -

52. Enters on $\underline{\mathbf{L B}}$ (LB or RB)

Enters on (LB or $R B)$

54. Confluence comments (eg. confluence name):

50. How many? 1

53. Type 1 (1- perennial; 2- ephemeral)

Type (1-perennial; 2- ephemeral)

$-$

55. Channel restraint (BF)? LB 2

\section{Under Bridge Channel Assessment}

\begin{tabular}{|c|c|c|c|c|c|c|c|}
\hline \multicolumn{2}{|c|}{ 56. Height (BF) } & \multicolumn{2}{|c|}{57 Angle (BF) } & \multicolumn{2}{|c|}{ 61. Material (BF) } & \multicolumn{2}{|c|}{ 62. Erosion (BF) } \\
\hline LB & RB & LB & RB & LB & RB & LB & RB \\
\hline & & & & 2 & 7 & 7 & - \\
\hline
\end{tabular}

58. Bank width (BF) -

59. Channel width $(\mathrm{Amb})$

60. Thalweg depth (Amb) $\mathbf{9 0 . 0}$

63. Bed Material -

Bed and bank Material: 0- organics; 1- silt / clay, < 1/16mm; 2- sand, 1/16 - 2mm; 3- gravel, 2 - 64mm; 4- cobble, 64 - 256mm; 5- boulder, > 256mm; 6- bedrock; 7- manmade

Bank Erosion: 0- not evident; 1- light fluvial; 2- moderate fluvial; 3- heavy fluvial / mass wasting

64. Comments (bank material variation, minor inflows, protection extent, etc.):

435 
65. Debris and Ice Is there debris accumulation?

$(Y$ or $N)$ 66. Where? $\mathbf{N}$

(1- Upstream; 2- At bridge; 3- Both)

67. Debris Potential ( 1- Low; 2- Moderate; 3- High)

68. Capture Efficiency 1 (1-Low; 2- Moderate; 3- High)

69. Is there evidence of ice build-up? 2 (Y or $N)$

Ice Blockage Potential $\underline{\mathbf{N}}$

(1- Low; 2- Moderate; 3- High)

70. Debris and Ice Comments:

2

There are trees along the banks but native stones offer protection. The capture efficiency of the bridge is increased because of the timber pier.

\begin{tabular}{|l|c|c|c|c|c|c|c|c|}
\hline Abutments & $\begin{array}{c}\text { 71. Attack } \\
\angle \text { (BF) }\end{array}$ & $\begin{array}{c}72 \text {. Slope } \angle \\
\text { (Qmax) }\end{array}$ & $\begin{array}{c}\text { 73. Toe } \\
\text { loc. (BF) }\end{array}$ & $\begin{array}{c}\text { 74. Scour } \\
\text { Condition }\end{array}$ & $\begin{array}{c}75 . \text { Scour } \\
\text { depth }\end{array}$ & $\begin{array}{c}\text { 76. Exposure } \\
\text { depth }\end{array}$ & 77. Material & 78. Length \\
\hline LABUT & & $\mathbf{0}$ & $\mathbf{9 0}$ & $\mathbf{2}$ & $\mathbf{2}$ & $\mathbf{0}$ & $\mathbf{1}$ & $\mathbf{9 0 . 0}$ \\
\hline RABUT & $\mathbf{1}$ & $\mathbf{0}$ & $\mathbf{9 0}$ & & & $\mathbf{2}$ & $\mathbf{2}$ & $\mathbf{2 1 . 5}$ \\
\hline
\end{tabular}

Pushed: $L B$ or RB

Toe Location (Loc.): 0- even, 1- set back, 2- protrudes

Scour cond.: 0- not evident; 1- evident (comment); 2- footing exposed; 3-undermined footing; 4- piling exposed; 5- settled; 6- failed

Materials: 1- Concrete; 2- Stone masonry or drywall; 3- steel or metal; 4- wood

79. Abutment comments (eg. undermined penetration, unusual scour processes, debris, etc.):

0

0.5

1

The maximum exposure of $1.2 \mathrm{ft}$ along the left abutment is at the downstream junction between the corner of the abutment and wingwall.

The maximum exposure of $0.7 \mathrm{ft}$ along the right abutment is at the downstream junction between the corner of the abutment and wingwall.

80. Wingwalls:

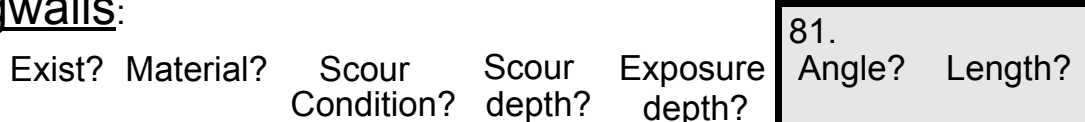

USLWW:

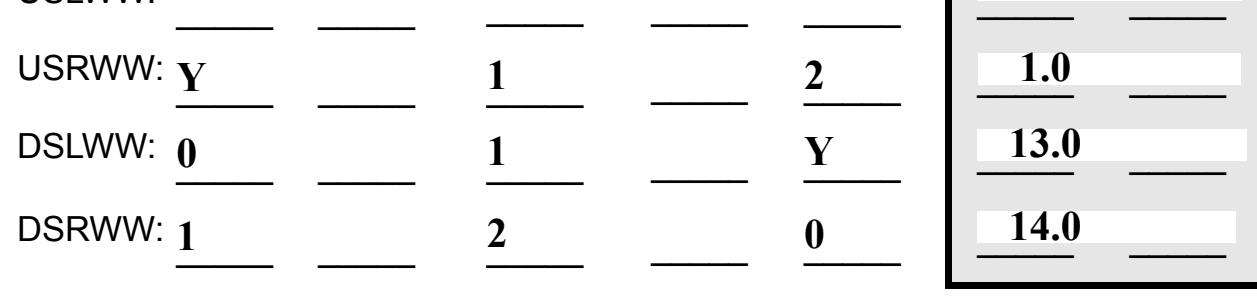

Wingwall materials: 1- Concrete; 2- Stone masonry or drywall; 3- steel or metal; 4- wood

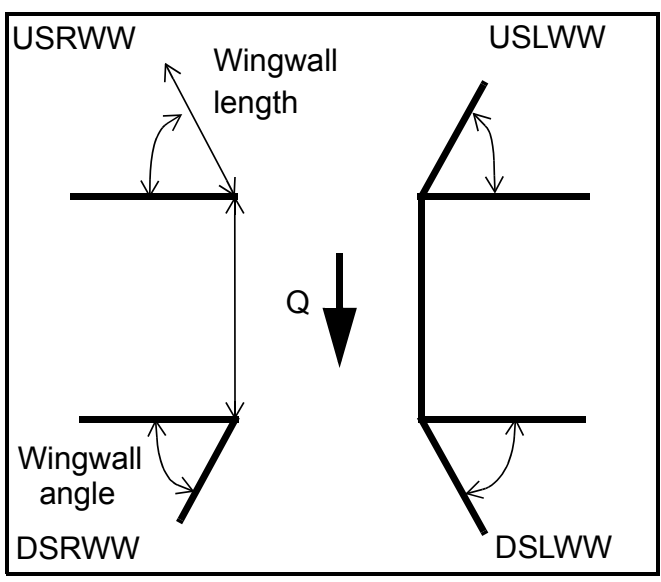

82. Bank / Bridge Protection:

\begin{tabular}{|l|l|l|l|l|l|l|l|l|}
\hline Location & USLWW & USRWW & LABUT & RABUT & LB & RB & DSLWW & DSRWW \\
\hline Type & $\mathbf{0 . 5}$ & $\mathbf{2}$ & $\mathbf{Y}$ & $\mathbf{0}$ & $\mathbf{1}$ & $\mathbf{1}$ & $\mathbf{1}$ & $\mathbf{3}$ \\
\hline Condition & $\mathbf{Y}$ & $\mathbf{0}$ & $\mathbf{1}$ & $\mathbf{1 . 0}$ & $\mathbf{1}$ & $\mathbf{1}$ & $\mathbf{1}$ & $\mathbf{1}$ \\
\hline Extent & $\mathbf{1}$ & $\mathbf{1 . 5}$ & $\mathbf{2}$ & $\mathbf{2}$ & $\mathbf{2}$ & $\mathbf{2}$ & $\mathbf{2}$ & - \\
\hline
\end{tabular}

Bank / Bridge protection types: 0- absent; 1-<12 inches; 2- < 36 inches; 3- < 48 inches; 4- < 60 inches; 
83. Wingwall and protection comments (eg. undermined penetration, unusual scour processes, etc.):

-
-
-
-
-
2
1
1
2
3
1

\section{Piers:}

84. Are there piers? _ _ (Y or if $N$ type ctrl-n pr)

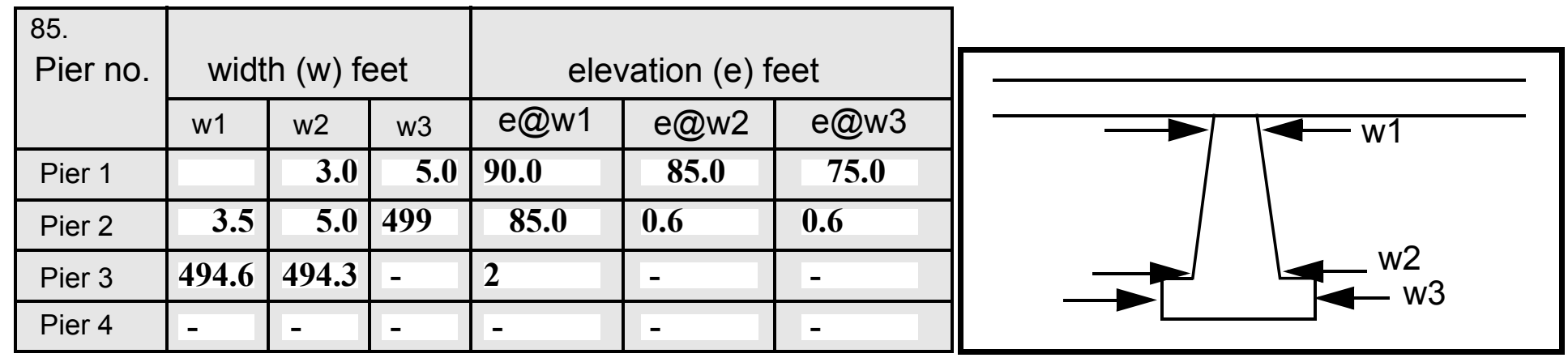

\begin{tabular}{|l|l|l|l|l|}
\hline Level 1 Pier Descr. & \multicolumn{1}{|c|}{2} & \multicolumn{2}{|c|}{3} & \multicolumn{1}{|l|}{} \\
\hline 86. Location (BF) & & M & - & - \\
\hline 87. Type & & 3 & - & - \\
\hline 88. Material & & $\mathbf{1}$ & - & - \\
\hline 89. Shape & & $\mathbf{2}$ & - & - \\
\hline 90. Inclined? & & $\mathbf{N}$ & - & - \\
\hline 91. Attack $\angle$ (BF) & & $\mathbf{0}$ & - & - \\
\hline 92. Pushed & & - & - & - \\
\hline 93. Length (feet) & - & - & - & - \\
\hline 94. \# of piles & & $\mathbf{U N K}$ & - & - \\
\hline 95. Cross-members & & $\mathbf{2}$ & - & - \\
\hline 96. Scour Condition & & $\mathbf{2}$ & - & - \\
\hline 97. Scour depth & $\mathbf{Y}$ & $\mathbf{0}$ & - & - \\
\hline 98. Exposure depth & $\mathbf{M C}$ & $\mathbf{0 . 8}$ & - & - \\
\hline
\end{tabular}

LFP, LTB, LB, MCL, MCM, MCR, RB, RTB, RFP

1- Solid pier, 2- column, 3- bent

1-Wood; 2- concrete; 3- metal; 4- stone

1- Round; 2- Square; 3- Pointed

Y-yes; $N$ - no

$L B$ or $R B$

0- none; 1- laterals; 2- diagonals; 3- both

0- not evident; 1- evident (comment);

2- footing exposed; 3- piling exposed;

4- undermined footing; 5- settled; 6 - failed 
99. Pier comments (eg. undermined penetration, protection and protection extent, unusual scour processes, etc.):

$-$

$-$

$-$

$-$

$-$

$-$

100.

\section{E. Downstream Channel Assessment}

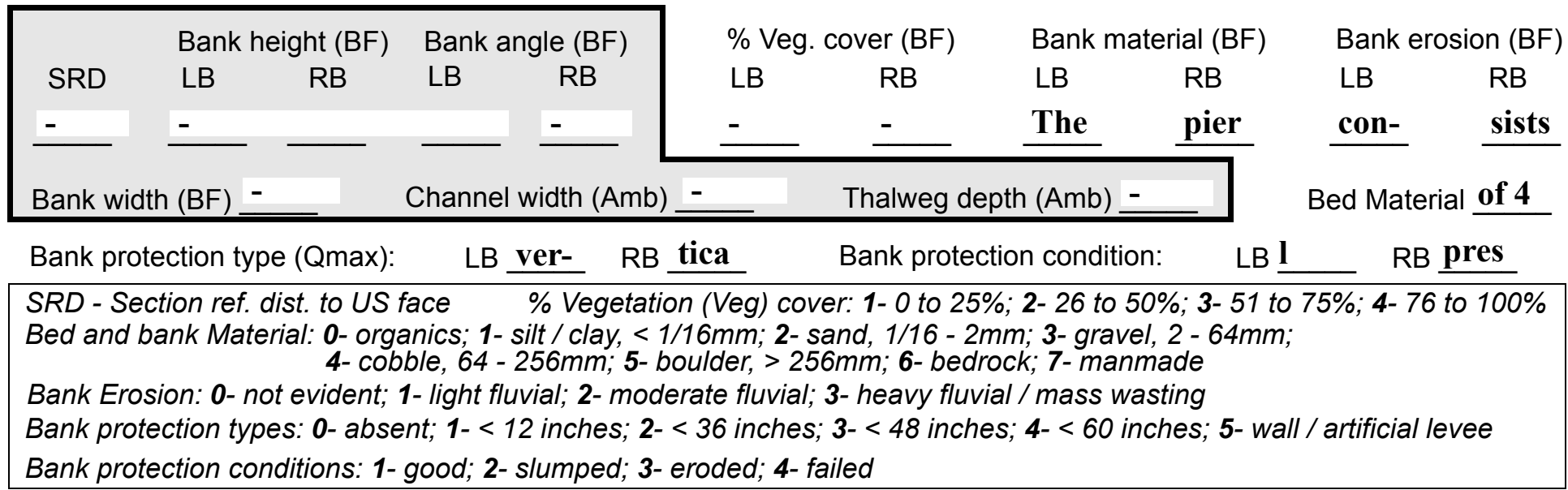

Comments (eg. bank material variation, minor inflows, protection extent, etc.):

sure treated timbers with 3 diagonal bents set on a pointed concrete footing. The footing is exposed 0.8 feet along the left side with the stream flowing around both sides.

1

101. Is a drop structure present? 1 ( $Y$ or $N$, if $N$ type ctrl-n ds) 102. Distance: __ feet
103. Drop: : feet
104. Structure material:

105. Drop structure comments (eg. downstream scour depth):

6

2

2

1

1

Placed stones extend $15 \mathrm{ft}$ along both banks with native stones extending beyond $300 \mathrm{ft}$ downstream on both 
106. Point/Side bar present? ba (Y or N. if $N$ type ctrl-n pb)Mid-bar distance: $\underline{\text { nks. }}$ Mid-bar width: Ther Point bar extent: $\underline{\text { e is a }}$ feet bed $(U S, U B, D S)$ to rock feet $\underline{\text { con }}$ (US, UB, DS) positioned tro \%LB to $\underline{\mathbf{l} \text { at }} \%$ RB Material: 140

Point or side bar comments (Circle Point or Side; note additional bars, material variation, status, etc.):

to $168 \mathrm{ft}$ downstream. Further steps extend to $230 \mathrm{ft}$ downstream with approximately a $20 \mathrm{ft}$ drop.

Is a cut-bank present?

Cut bank extent: feet (Y or if $N$ type ctrl- $n$ cb) Where? (LB or $R B)$ feet (US, UB, DS)

Bank damage: (US, UB, DS) to (1- eroded and/or creep; 2- slip failure; 3- block failure)

Cut bank comments (eg. additional cut banks, protection condition, etc.):

\section{$\mathbf{N}$}

There is no drop structure downstream at this site. Is channel scour present? ( $Y$ or if $N$ type ctrl-n cs) Mid-scour distance: Scour dimensions: Length Width Depth: Mid-bank distance:

Scour comments (eg. additional scour areas, local scouring process, etc.):

$-$

$-$

-

Are there major confluences? ( $Y$ or if $N$ type ctrl-n $m c)$

How many? -

Confluence 1: Distance Enters on ( $L B$ or $R B)$

Confluence 2: Distance re

Enters on are ( $L B$ or $R B)$

Confluence comments (eg. confluence name):

pointbars downstream at this site.

\section{F. Geomorphic Channel Assessment}

107. Stage of reach evolution
1- Constructed

2- Stable

3- Aggraded

4- Degraded

5- Laterally unstable

6- Vertically and laterally unstable 
108. Evolution comments (Channel evolution not considering bridge effects; See HEC-20, Figure 1 for geomorphic descriptors):

$\mathbf{Y}$

LB

40

15

DS

75

DS

1

$-$ 


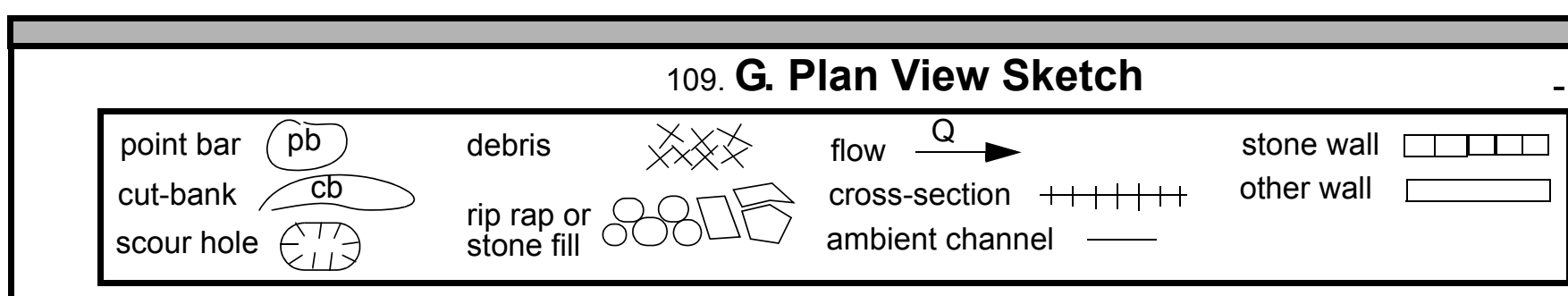


APPENDIX F:

SCOUR COMPUTATIONS 
SCOUR COMPUTATIONS

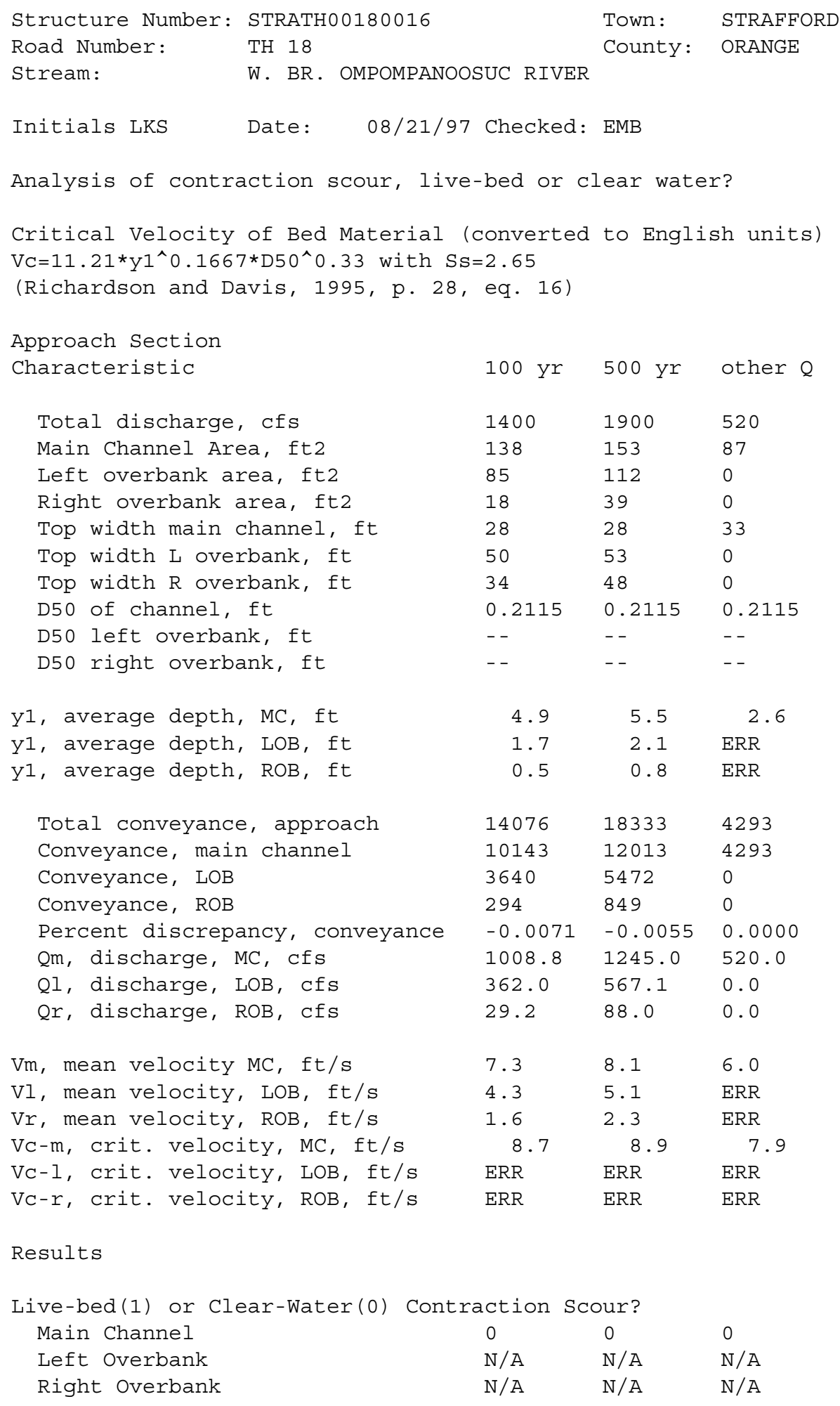


Clear water Contraction scour in MAIN CHANNEL

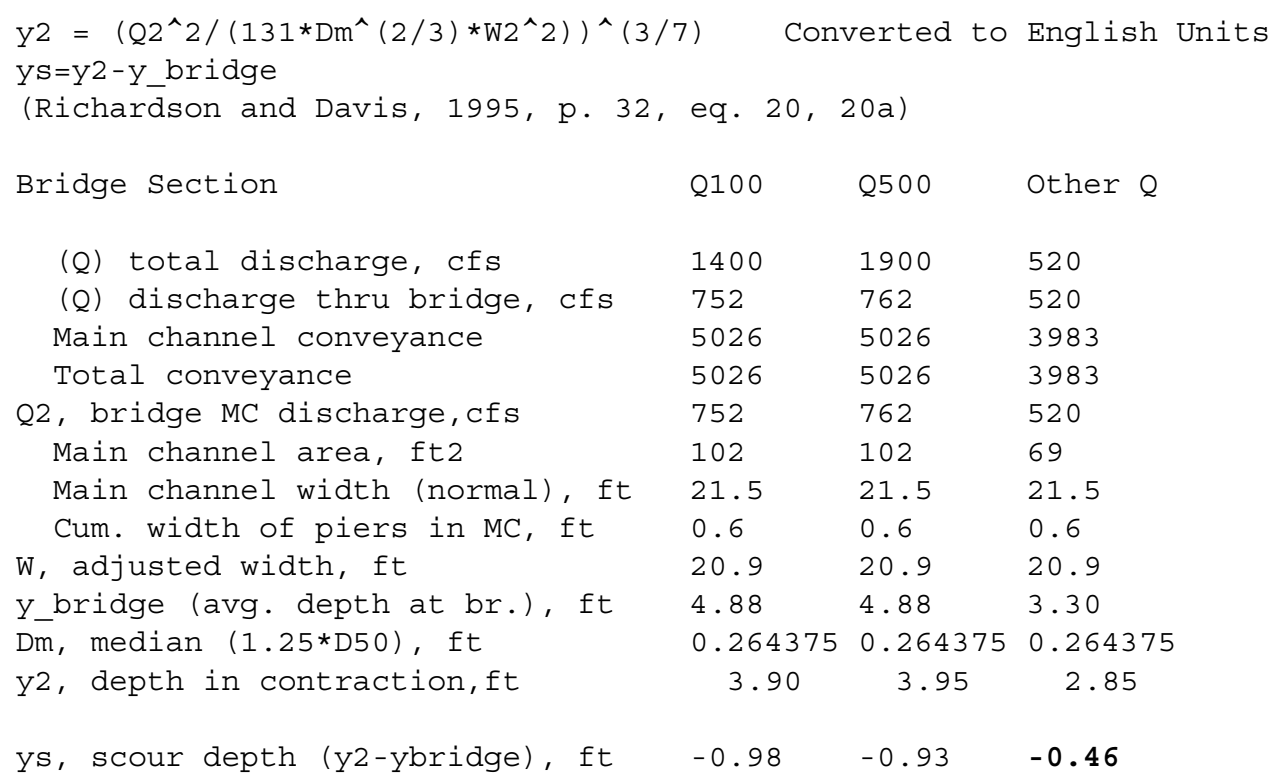

\section{Armoring}

$\mathrm{DC}=\left[\left(1.94 * \mathrm{~V}^{\wedge} 2\right) /(5.75 * \log (12.27 * \mathrm{y} / \mathrm{D} 90))^{\wedge} 2\right] /[0.03 *(165-62.4)]$

Depth to Armoring=3* (1/PC-1)

(Federal Highway Administration, 1993)

Q, discharge thru bridge MC, cfs $752 \quad 762 \quad 520$

Main channel area (DS), ft2 $102 \quad 102 \quad 69$

Main channel width (normal), ft $21.5 \quad 21.5 \quad 21.5$

Cum. width of piers, ft $\quad 0.6 \quad 0.6 \quad 0.6$

Adj. main channel width, ft $\quad 20.9 \quad 20.9 \quad 20.9$

$\begin{array}{llll}\text { D90, ft } & 0.6498 & 0.6498 & 0.6498\end{array}$

$\begin{array}{lllll}\text { D95, ft } & 0.8727 & 0.8727 & 0.8727\end{array}$

$\begin{array}{lllll}\text { Dc, critical grain size, ft } & 0.2685 & 0.2757 & 0.3361\end{array}$

PC, Decimal percent coarser than DC $0.355 \quad 0.339 \quad 0.251$

Depth to armoring, ft $\quad \begin{array}{lll}1.46 & 1.61 & 3.01\end{array}$ 
Pressure Flow scour (contraction scour for orifice flow conditions)

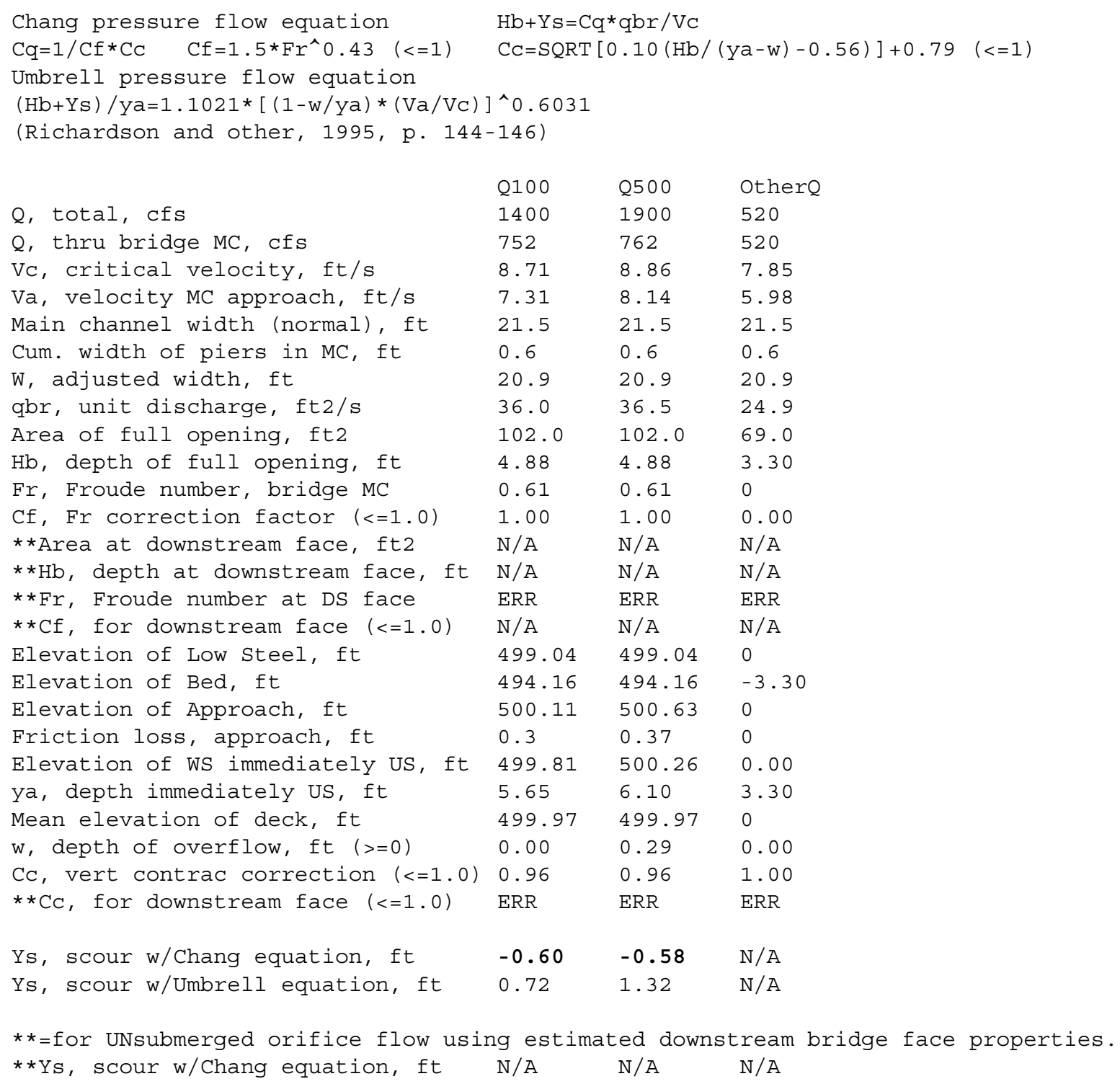




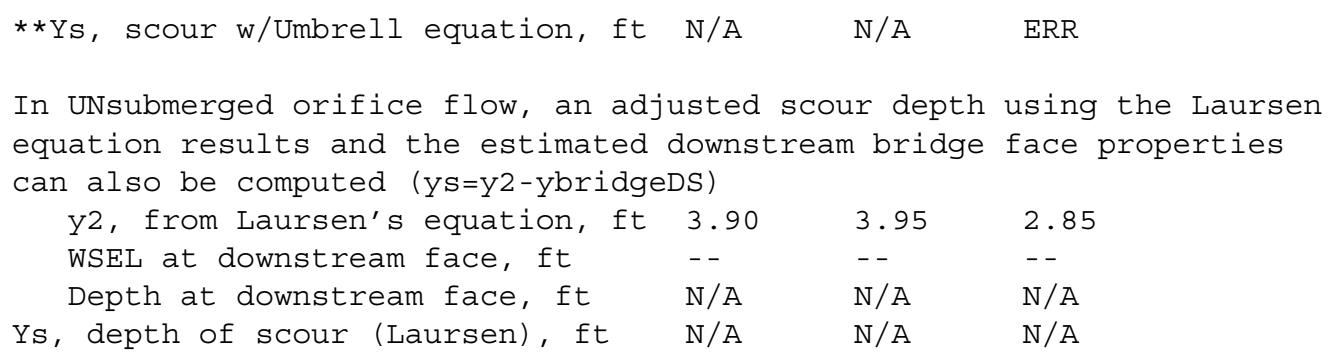

\section{Abutment Scour}

Froehlich's Abutment Scour $\mathrm{Ys} / \mathrm{Y} 1=2.27 * \mathrm{~K} 1 * \mathrm{~K} 2 *\left(\mathrm{a}^{\prime} / \mathrm{Y} 1\right)^{\wedge} 0.43 * \mathrm{Fr} 1^{\wedge} 0.61+1$ 


\begin{tabular}{|c|c|c|c|c|c|c|}
\hline$a^{\prime}$ (abut length blocked, ft) & 49.8 & 53.5 & 6.4 & 40.8 & 54.7 & 5.4 \\
\hline y1 (depth f/p flow, ft) & 0.66 & 0.51 & 0.91 & 0.86 & 0.80 & 1.49 \\
\hline$a^{\prime} / y 1$ & 75.66 & 104.96 & 7.03 & 47.45 & 68.38 & 3.62 \\
\hline Skew correction (p. 49, fig. 16) & 0.98 & 0.98 & 0.98 & 1.01 & 1.01 & 1.01 \\
\hline Froude no. f/p flow & 0.57 & 0.61 & 0.47 & 0.61 & 0.59 & 0.56 \\
\hline Ys w/ corr. factor $\mathrm{K} 1 / 0.55$ : & 3.90 & 3.10 & & & & $E R R$ \\
\hline vertical w/ ww's & 3.20 & $\begin{array}{l}3.10 \\
2.54\end{array}$ & $\begin{array}{l}\text { ERR } \\
\text { ERR }\end{array}$ & $\begin{array}{l}5.38 \\
4.41\end{array}$ & $\begin{array}{l}4.93 \\
4.05\end{array}$ & $\begin{array}{l}\mathrm{ERR} \\
\mathrm{ERR}\end{array}$ \\
\hline spill-through & 2.15 & 1.71 & $\mathrm{ERR}$ & 2.96 & 2.71 & ERR \\
\hline \multicolumn{7}{|l|}{ Abutment riprap sizing } \\
\hline \multirow{2}{*}{\multicolumn{7}{|c|}{$\begin{array}{l}\text { Isbash Relationship } \\
\mathrm{D} 50=\mathrm{Y}^{\star} \mathrm{K} * \mathrm{Fr} \mathrm{F}^{\wedge} /(\mathrm{Ss}-1) \text { and } \mathrm{D} 50=\mathrm{y} * \mathrm{~K} *\left(\mathrm{Fr} r^{\wedge}\right)^{\wedge} 0.14 /(\mathrm{Ss}-1) \\
\text { (Richardson and Davis, 1995, p112, eq. 81,82) }\end{array}$}} \\
\hline & & & & & & \\
\hline Characteristic & Q100 & Q500 & Other $Q$ & Q100 & Q500 & Other $\mathrm{Q}$ \\
\hline Fr, Froude Number & 0.63 & 0.62 & 0.95 & 0.63 & 0.62 & 0.95 \\
\hline y, depth of flow in bridge, ft & 4.90 & 7.14 & 4.09 & 4.90 & 7.14 & 4.09 \\
\hline Median stone Diameter for riprap & left & atment & & right & abutment, & ft \\
\hline Fr $<=0.8$ (vertical abut.) & 1.20 & 1.70 & ERR & 1.20 & 1.70 & ERR \\
\hline Fr>0.8 (vertical abut.) & ERR & ERR & 1.69 & ERR & ERR & 1.69 \\
\hline
\end{tabular}

\section{Pier Scour}

$\mathrm{Ys} / \mathrm{Y} 1=2.0 * \mathrm{~K} 1 * \mathrm{~K} 2 * \mathrm{~K} 3 * \mathrm{~K} 4 *(\mathrm{a} / \mathrm{Y} 1) \wedge 0.65 * \mathrm{Fr} 1 \wedge 0.43$

(Richardson and Davis, 1995, p. 36, eq. 21)

K1, corr. factor for pier nose shape

Sharp nose, 0.9; round nose, cylinder, or cylinder grp., 1.0; square nose, 1.1

K2, corr. factor attack angle (see Table 3, p 37)

$$
\mathrm{K} 2=[\cos (\text { attackangle })+\mathrm{L} / \mathrm{a} * \sin (\text { attackangle })]^{\wedge} 0.65
$$

K3, corr. factor for bed condition

Clear-water, plane bed, antidune, 1.1; med. dunes, 1.1-1.2 (see Tab.4,p37)

K4, corr. factor for armoring (the following equations are in Si units)

$\mathrm{K} 4=\left[1-0.89 *(1-\mathrm{Vr})^{\wedge} 2\right]^{\wedge} 0.5$

$\mathrm{Vr}=(\mathrm{V} 1-\mathrm{Vi}) /(\mathrm{VC} 90-\mathrm{Vi})$

$\mathrm{V} 1=0.645 *\left((\mathrm{D} 50 / \mathrm{a})^{\wedge} 0.053\right) * \mathrm{VC} 50$

$\mathrm{VC}=6.19 *\left(\mathrm{Y}^{\wedge} 1 / 6\right) *\left(\mathrm{DC}^{\wedge} 1 / 3\right)$

Note for round nose piers:

ys $<=2.4$ times the pier width (a) for Fr<=0.8

ys $<=3.0$ times the pier width (a) for Fr>0.8 


\begin{tabular}{|c|c|c|c|}
\hline Pier 1 & Q100 & Q500 & Qother \\
\hline Pier stationing, ft & 10.8 & 10.8 & 10.8 \\
\hline Area of WSPRO flow tube, ft2 & 4.6 & 4.6 & 3.1 \\
\hline Skewed width of flow tube, ft & 0.797 & 0.897 & 0.697 \\
\hline y1, pier approach depth, ft & 5.77 & 5.13 & 4.45 \\
\hline y1 in meters & 1.759 & 1.563 & 1.356 \\
\hline V1, pier approach velocity, ft/s & 8.25 & 8.36 & 8.46 \\
\hline a, pier width, ft & 0.6 & 0.6 & 0.6 \\
\hline L, pier length, ft & 10.6 & 10.6 & 10.6 \\
\hline Fr1, Froude number at pier & 0.605 & 0.651 & 0.707 \\
\hline Pier attack angle, degrees & 0 & 0 & 0 \\
\hline K1, shape factor & 1.1 & 1.1 & 1.1 \\
\hline $\mathrm{K} 2$, attack factor & 1.00 & 1.00 & 1.00 \\
\hline K3, bed condition factor & 1.1 & 1.1 & 1.1 \\
\hline D50, ft & 0.2115 & 0.2115 & 0.2115 \\
\hline $\mathrm{D} 50, \mathrm{~m}$ & 0.064462 & 0.064462 & 0.064462 \\
\hline D90, ft & 0.6498 & 0.6498 & 0.6498 \\
\hline $\mathrm{D} 90, \mathrm{~m}$ & 0.198049 & 0.198049 & 0.198049 \\
\hline Vc50, critical velocity (D50), m/s & 2.727 & 2.674 & 2.611 \\
\hline Vc 90 , critical velocity (D90), m/s & 3.964 & 3.887 & 3.796 \\
\hline Vi,incipient velocity, m/s & 1.664 & 1.632 & 1.594 \\
\hline Vr, velocity ratio & 0.370 & 0.406 & 0.447 \\
\hline K4, armor factor & 0.80 & 0.83 & 0.85 \\
\hline ys, scour depth (K4 applicable) ft & 2.08 & 2.12 & 2.15 \\
\hline ys, scour depth (K4 not applied) ft & ERR & ERR & ERR \\
\hline \multirow{2}{*}{\multicolumn{4}{|c|}{$\begin{array}{l}\text { Pier rip-rap sizing } \\
\text { D50=0.692 }(\mathrm{K} * \mathrm{~V}) \wedge 2 /(\mathrm{Ss}-1) * 2 * \mathrm{~g} \\
\text { (Richardson and Davis, } 1995, \mathrm{p} .115 \text {, eq. } 83) \\
\text { Pier-shape coefficient (K), round nose, } 1.5 \text {; square nose, } 1.7 \\
\text { Characteristic avg. channel velocity, } \mathrm{V},(\mathrm{Q} / \mathrm{A}): \\
\text { (Mult. by } 0.9 \text { for bankward piers in a straight, uniform reach, } \\
\text { up to } 1.7 \text { for a pier in main current of flow around a bend) }\end{array}$}} \\
\hline & & & \\
\hline \multicolumn{2}{|l|}{ Pier 1} & Q100 & Qother \\
\hline \multicolumn{2}{|l|}{$\begin{array}{l}\mathrm{K} \text {, pier shape coeff. } \\
\mathrm{V} \text {, velocity on pier } \mathrm{ft} / \mathrm{s}\end{array}$} & 1.7 & 1.7 \\
\hline $\mathrm{V}$, velocity on pier, ft/s & & 8.25 & 8.4 \\
\hline D50, median stone dia & & 1.28 & 1.33 \\
\hline
\end{tabular}


